\title{
DNA damage response at functional and dysfunctional telomeres
}

\author{
Maria Pia Longhese ${ }^{1}$ \\ Dipartimento di Biotecnologie e Bioscienze, Università di Milano-Bicocca, 20126 Milan, Italy
}

The ends of eukaryotic chromosomes have long been defined as structures that must avoid being detected as DNA breaks. They are protected from checkpoints, homologous recombination, end-to-end fusions, or other events that normally promote repair of intrachromosomal DNA breaks. This differentiation is thought to be the consequence of a unique organization of chromosomal ends into specialized nucleoprotein complexes called telomeres. However, it is becoming increasingly clear that proteins governing the DNA damage response are intimately involved in the regulation of telomeres, which undergo processing and structural changes that elicit a transient DNA damage response. This suggests that functional telomeres can be recognized as DNA breaks during a temporally limited window, indicating that the difference between a break and a telomere is less defined than previously assumed.

DNA double-strand breaks (DSBs) are among the most deleterious types of damage that can occur in the genome of eukaryotic cells, because failure to repair these lesions can lead to serious genetic instability. DNA breaks must be recognized as DNA damage to activate checkpoints and repair/recombination pathways, whose primary function is to repair the break. The natural ends of linear chromosomes must be distinguished from intrachromosomal DSBs to prevent triggering of DNA damage checkpoint and repair/recombination machineries. Here, I first summarize the features of both DSBs and telomeres and the current views on how telomerase is assembled and activated at telomeres. Then, I focus on the mechanisms protecting chromosome ends and how functional and dysfunctional telomeres can elicit a DNA damage response.

\section{Telomere structure and homeostasis}

Telomeres are specialized nucleoprotein complexes that define the physical ends of linear chromosomes. Their basic structure is conserved among eukaryotes and con-

[Keywords: Telomere; double-strand break; checkpoint; ATM/Tell; ATR/Mec1]

${ }^{1}$ Correspondence.

E-MAIL mariapia.longhese@unimib.it; FAX 390264483565.

Article is online at http://www.genesdev.org/cgi/doi/10.1101/gad.1626908. sists of short tandem DNA repeats, which are G-rich in the strand containing the $3^{\prime}$-end. This strand is referred to as the G-strand, whereas the $5^{\prime}$-end containing the complementary strand is called the C-strand (Fig. 1). The G-strand extends beyond its complementary C-rich strand to form a single-stranded overhang, referred to as the G-tail. In mammals, the single-stranded telomeric 3' overhang invades the double-stranded telomeric DNA, base-pairing with the $\mathrm{C}$-strand and displacing the G-strand. Because this strand invasion takes place at a distance from the physical end of the telomere, it generates a large duplex structure called the t-loop (Fig. 1A, top; Griffith et al. 1999). Similar structures have been reported to exist also in Kluyveromyces lactis, ciliates, and trypanosomes (Murti and Prescott 1999; MuñozJordán et al. 2001; Cesare et al. 2007). Telomeres can also fold into G-quadruplex DNA, an unusual DNA conformation that is based on a guanine quartet (Parkinson et al. 2002).

Telomere length is maintained by a dynamic process of lengthening and shortening. Shortening can occur as a result of nucleolytic degradation and incomplete DNA replication, whereas lengthening is primarily accomplished by the action of a specialized reverse transcriptase called telomerase (Greider and Blackburn 1985) and occasionally by homologous recombination (HR) (Liu et al. 2007). Telomerase extends the 3' G-rich strand of a chromosome by reverse-transcribing the template region of its tightly associated RNA moiety. Although in vitro telomerase activity requires both its reverse transcriptase catalytic subunit (Est2 in Saccharomyces cerevisiae and TERT in mammals) and the RNA template (TLC1 in S. cerevisiae and hTR in humans), other factors are required for telomerase action in vivo. For instance, effective telomerase function in $S$. cerevisiae requires Est1 and Est3. The conventional DNA replication machinery can then fill in the C-rich strand, thus preventing any loss of DNA (for review, see Hug and Lingner 2006).

Notably, by following the elongation of a single telomere in yeast, it has been shown that telomerase does not act on every telomere in each cell cycle but instead exhibits an increasing preference for telomeres as their lengths decline, suggesting that telomeres switch between nonextendible and extendible states (Teixeira et al. 2004). The number of nucleotides added to a telomere in a single cell cycle varies between a few and $>100$ 
A
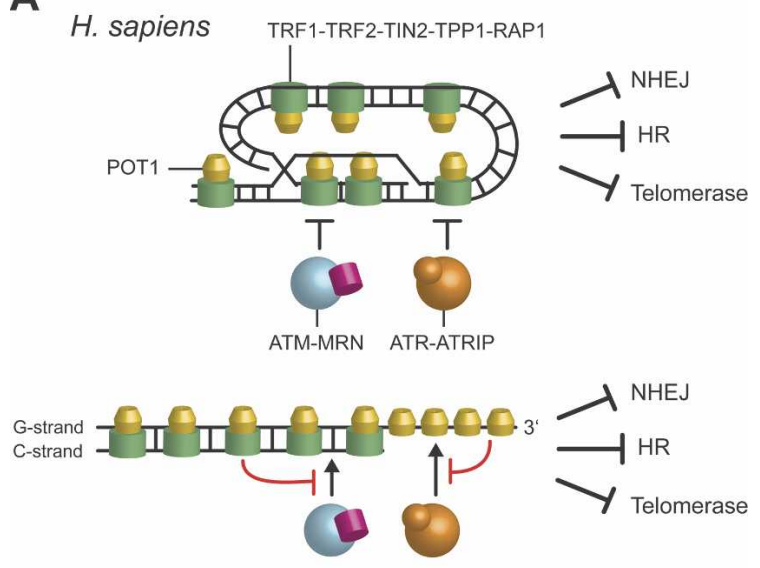

B

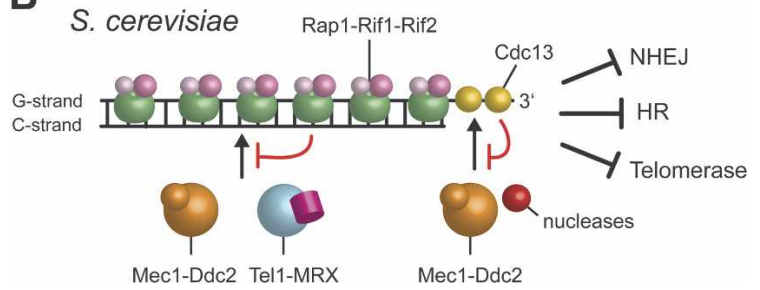

Figure 1. How chromosome end protection can be achieved. $(A, t o p)$ In humans, telomeres folding into t-loops may protect the chromosome ends from NHEJ and HR. Moreover, t-loop structures may also inhibit the recruitment of telomerase and checkpoint proteins. (Bottom) For telomeres that do not adopt a t-loop conformation, the ssDNA-binding protein POT1 is thought to inhibit both ATR activation by blocking RPA recruitment to the telomeric ssDNA, and telomerase action. The dsDNA-binding protein TRF2 is proposed to prevent ATM activation. (B) In $S$. cerevisiae, Rap1 is thought to inhibit the recruitment of MRX, RPA, Mec1, and telomerase at telomeres, whereas Cdc13 binding to single-stranded telomere sequences prevents nucleases from binding, therefore inhibiting RPA recruitment and subsequent Mec1-dependent checkpoint activation.

nucleotides (nt). Telomere length affects telomerase repeat addition processivity in vivo (Chang et al. 2007). In fact, by examining the telomere extensions after one cell cycle, it has been shown that $S$. cerevisiae telomerase can dissociate from and reassociate to a given telomere during one round of telomere elongation. Repeat addition processivity is enhanced at extremely short telomeres, allowing cells to rapidly elongate them (Chang et al. 2007).

Although the presence of a functional telomerase is a necessary condition for telomere maintenance, it is not sufficient. ssDNA- and dsDNA-binding proteins with specificity for telomeric TG repeats are required to regulate telomerase activity and to protect chromosome ends from degradation and end-to-end joining events. In S. cerevisiae, Cdc13, which exhibits structural similarities to the ssDNA-binding protein Replication Protein A (RPA) (Gao et al. 2007), binds the single-stranded G-tail (Fig. 1B) and allows telomerase recruitment to the telomeric 3'-end (Nugent et al. 1996; Pennock et al. 2001; Bianchi et al. 2004). Moreover, Cdc13 limits telomerase-mediated telomere elongation in conjunction with Stn 1 and Ten1, two essential Cdc13-associated proteins (Grandin et al. 1997, 2001; Chandra et al. 2001).

In both fission yeast and vertebrates, the POT1 (protection of telomeres 1) protein binds the single-stranded overhang on the 3' G-rich strand with high sequence specificity using two oligonucleotide/oligosaccharidebinding (OB) folds (Fig. 1A; Baumann and Cech 2001; Loayza and de Lange 2003; Lei et al. 2004). Mammalian POT1 forms the so-called shelterin complex with the telomeric-repeat-binding factor 1 (TRF1), TRF2, TRF-interacting protein 2 (TIN2), the transcriptional repressor/ activator protein RAP1, and the POT1- and TIN2-organizing protein TPP1 (Liu et al. 2004; for a review, see de Lange 2005). TRF1 and TRF2 bind double-stranded telomeric repeats and anchor the complex along the length of telomeres (Fig. 1A; Chong et al. 1995; Bilaud et al. 1997; Broccoli et al. 1997; Court et al. 2005). TRF1 and TRF2 recruit TIN2 (Kim et al. 1999), which can form a bridge with POT1 via TPP1 (Baumann and Cech 2001; Houghtaling et al. 2004; Liu et al. 2004; Ye et al. 2004b). TIN2 also connects TRF1 to TRF2, and this link contributes to the stabilization of TRF2 on telomeres (Houghtaling et al. 2004; Liu et al. 2004; Ye et al. 2004a). POT1 not only interacts with single-stranded telomeric DNA, but also accumulates along the duplex telomeric repeat array (Ye et al. 2004b). TRF2 also interacts directly with RAP1 and POT1 (Li et al. 2000; Yang et al. 2005).

Shelterin-related proteins are also found at telomeres in other eukaryotes. For example, POT1-like proteins are present in nearly all eukaryotes, and TRF1- and TRF2like proteins are found in fission yeast and trypanosomes (Cooper et al. 1997; Li et al. 2005; Pitt et al. 2007), whereas Rapl is present in fission yeast (Kanoh and Ishikawa 2001). Moreover, S. cerevisiae Rapl is a highly divergent TRF ortholog, which binds double-stranded telomeric DNA together with its interacting factors Rif1 and Rif2 (Fig. 1B; Conrad et al. 1990; Hardy et al. 1992; Kyrion et al. 1992).

In both mammals and yeast, the shelterin and shelterin-like complexes negatively regulate telomerase by sequestering its DNA substrate in a closed conformation. In budding yeast, the Rap1 protein negatively regulates telomere length (Conrad et al. 1990; Marcand et al. 1997), and the Rap1-binding proteins Rif1 and Rif2 contribute to this negative regulation (Levy and Blackburn 2004). In fission yeast, loss of Taz1, a double-strand telomere-binding protein orthologous to TRF1 and TRF2, results in uncontrolled elongation of both the double- and single-stranded telomeric tracts (Cooper et al. 1997). In humans, TRF1 or TRF2 overexpression causes telomere shortening without affecting in vitro telomerase activity, whereas overexpression of a DNA-binding-deficient TRF1 variant results in progressive telomere elongation (van Steensel and de Lange 1997; Smogorzewska et al. 2000). In humans, reduction of TIN2 protein levels or overexpression of TIN2 mutant alleles that disrupt TIN2 interaction with TRF1 and TRF2 leads to telomere 
lengthening (Kim et al. 2004; Ye et al. 2004b). Reduction of Rap1 protein levels also leads to mild telomere lengthening ( $\mathrm{Li}$ and de Lange 2003; O'Connor et al. 2004).

A critical feature of this in cis negative regulation of telomerase access is the ability of shelterin to limit telomere length based on its total telomere-bound amount, which generates an inhibitory effect on telomerase, whose strength increases with increasing TG tract length (Marcand et al. 1997). Because the amount of shelterin and shelterin-like proteins bound to a telomere is proportional to the length of the TG repeat array, longer telomeres are proposed to have a greater probability of inhibiting telomerase access. Progressive telomere shortening causes the gradual loss of telomere-bound shelterin, and therefore a progressive relief of its inhibitory function on telomerase activity, thus allowing telomerase-mediated telomere elongation.

One possibility is that regulation of telomerase activity by shelterin is achieved at the level of its association with the telomere. In S. cerevisiae, studies of telomeric protein association to short and normal-length telomeres show that Est1 and Est2 are preferentially recruited to a shortened telomere, which is known to be a preferential substrate for telomerase (Bianchi and Shore 2007; Sabourin et al. 2007). Because Cdc13 loading to TG tracts is not regulated by telomere length (Bianchi and Shore 2007), this suggests that it is Cdc13 ability to recruit telomerase to telomeres that can be subjected to regulation by protein-bound TG tracks. In humans, regulation of telomerase activity might occur through the shelterin component POT1 (Loayza and de Lange 2003; Liu et al. 2004). In fact, overexpression of a mutant form of POT1 lacking the DNA-binding domain abrogates TRF1-mediated control of telomere length and induces rapid and extensive telomere elongation (Loayza and de Lange 2003). Moreover, in Tetrahymena thermofila, which contains two POT1 isoforms, POT1a removal results in telomere elongation (Jacob et al. 2007). Because in vitro association of recombinant human POT1 with telomere oligonucleotide ends inhibits telomerase binding (Kelleher et al. 2005; Lei et al. 2005), it has been proposed that POT1 limits telomerase from gaining access to the Gtail. Thus, the presence of more shelterin on longer telomeres increases the loading of POT1 on the telomeric overhang, where it blocks telomerase action.

\section{Generation of ssDNA overhangs at both telomeres and DSBs}

Although telomeric ends are apparently shielded from being recognized as DSBs, chromosome ends and accidental interruptions in duplex DNA molecules share important similarities. In fact, accidental DSBs are resected by $5^{\prime}-3^{\prime}$ exonucleases to generate $3^{\prime}$-ended ssDNA tails, which are channeled into different homology-dependent recombination pathways. The ends of chromosomes in humans, mice, ciliates, yeast, trypanosomes, and plants also carry ssDNA G-tails that serve as substrate for telomerase. Single-stranded G-tails of 50-100 nt are transiently detected in S. cerevisiae telomeres in late S phase
(Wellinger et al. 1993), while G-tails of 12-14 nt are present outside of $S$ phase during the rest of the cell cycle (Larrivee et al. 2004). Accordingly, the Cdc13 protein is bound at $S$. cerevisiae telomeres throughout the cell cycle, with a maximal association in S phase, concomitantly with the increased amount of single-stranded telomeric DNA (Taggart et al. 2002). The RPA complex is also present at budding yeast telomeres, and its association increases during $S$ phase (Schramke et al. 2004). In human telomeres, longer G-tails of 75-300 nt are detected throughout the cell cycle (Makarov et al. 1997; Wright et al. 1997).

These protruding G-strand overhangs play a central role in modulating telomere homeostasis, since they serve as a substrate for extension by telomerase (for a review, see Gilson and Geli 2007). While single-stranded G-tails can be generated during lagging-strand replication after removal of the last RNA primer, the chromosome end that is generated by the leading-strand polymerase is expected to be blunt-ended, hence lacking a G-tail (Lingner et al. 1995; Chai et al. 2006a). However, single-stranded G-tails can be detected at both ends of a chromosome even in the absence of telomerase (Wellinger et al. 1996; Makarov et al. 1997), suggesting the existence of an activity recessing the C-strand of newly synthesized blunt-ended molecules after completion of the leading-strand replication. Whether a $5^{\prime}$ resection activity also processes the lagging telomere is still unknown.

The nucleolytic processing of both accidental DSBs and telomeres depends on a multifunctional highly conserved trimeric complex, known as MRN (Mre11Rad50-Nbs1) in humans and MRX (Mre11-Rad50-Xrs1) in S. cerevisiae. In fact, resection of DNA ends generated in $S$. cerevisiae by the homothallic $(\mathrm{HO})$ endonuclease partially depends on the MRX complex (Ivanov et al. 1994; Clerici et al. 2006). Moreover, MRX/MRN appears to be important for single-stranded G-tail generation, at least in the de novo telomere addition reaction (Diede and Gottschling 2001), and is required for wild-type length G-tails in both S. cerevisiae and humans (Larrivee et al. 2004; Chai et al. 2006b).

Mre11 contains four conserved N-terminal phosphoesterase motifs, and both human and budding yeast Mre11 harbor ssDNA endonuclease, $3^{\prime}-5^{\prime}$ dsDNA exonuclease, and DNA unwinding and DNA annealing activities (for a review, see Williams et al. 2007), suggesting that Mre11 nuclease activity may be responsible for end resection at both DSBs and telomeres. However, S. cerevisiae mre11 nuclease-defective alleles cause only a mild sensitivity to ionizing radiations (IR) and do not seem to affect either resection of DNA ends generated by HO- or IR-induced sister chromatid recombination (Moreau et al. 1999). Moreover, although the nucleasedeficient mre11 alleles block de novo telomere addition in G2, they allow normal telomere maintenance in cycling cells (Frank et al. 2006). This suggests that properties of MRX other than the nuclease activity are important to allow resection of both DSBs and telomeric ends. In any case, the disruption of the S. cerevisiae MRX complex does not completely abolish either DSB resection or 
G-tail generation (Larrivee et al. 2004; Clerici et al. 2006; Frank et al. 2006), suggesting the presence of redundant nuclease activities at both DSBs and telomeres. In S. cerevisiae, Exol may be one of these exonucleases, since the absence of MRX allows additional 5' resection of DSBs that is partially dependent on Exol (Llorente and Symington 2004; Clerici et al. 2006). Moreover, this exonuclease plays a critical role in C-strand resection at uncapped telomeres in yeast cells defective for $\mathrm{Cdc} 13$ or lacking the nonhomologous end joining (NHEJ) factor yKu70 (Maringele and Lydall 2002; Zubko et al. 2004).

In humans, shelterin appears to regulate the nucleolytic processing of the $5^{\prime} \mathrm{C}$-strand. In fact, when human TRF2 is inhibited, the overall amount of single-stranded TTAGGG repeats is diminished (van Steensel et al. 1998; Celli and de Lange 2005). Remarkably, TRF2 physically interacts with Apollo, whose $\mathrm{N}$-terminal domain is closely related to that of Artemis, a factor involved in $\mathrm{V}(\mathrm{D}) \mathrm{J}$ recombination and DNA repair (Lenain et al. 2006; van Overbeek and de Lange 2006). Apollo exhibits a 5'-to-3' DNA exonuclease activity in vitro, raising the possibility that it might contribute to the resection of the C-rich strand of telomeric DNA (Lenain et al. 2006).

Generation of ssDNA at both DSBs and telomeres requires the activity of cyclin-dependent kinases (CDK), whose sequential action determines cell cycle progression. In fact, inhibition of $S$. cerevisiae Cdk1 activity in G2-arrested cells prevents DSB processing and HO-induced DSB repair by HR (Ira et al. 2004; Aylon and Kupiec 2005; Jazayeri et al. 2006). Moreover, inhibition of an ATP analog-sensitive variant of Cdk1 completely blocks the addition of telomere repeats in a de novo telomere addition assay and prevents generation of G-strand overhangs at both native and uncapped $S$. cerevisiae cdc13-1 telomeres (Frank et al. 2006; Vodenicharov and Wellinger 2006). In G1 cells, the Clb-Cdk1 complexes are kept inactive by their inhibitor Sicl. Therefore, resection at telomeres is limited to late $\mathrm{S}$ and $\mathrm{G} 2 / \mathrm{M}$, coinciding with a time frame in which the length of the G-tails increases and telomerase can elongate telomeric DNA (Wellinger et al. 1993; Marcand et al. 2000). Interestingly, Cdk1 activity is necessary but not sufficient for degradation of $S$. cerevisiae unprotected telomeres, which also requires the passage of the replication fork (Dionne and Wellinger 1998; Vodenicharov and Wellinger 2006). This suggests that the Clb-Cdk1-dependent processing activity may be brought to telomeres by the replication fork. Since HR relies on ssDNA 3' overhangs to initiate strand invasion, the dependence of $5^{\prime}$ strand resection on active Clb-Cdk1 complexes indicates that Clb-Cdk1 activity also controls recombination at both telomeres and DSBs. The targets through which $\mathrm{Clb}-$ Cdk1 stimulates end resection are not known. Because the MRX complex is required to process both DSBs and telomeres, it might be a potential target of Clb-Cdk1.

\section{Intrachromosomal DSBs elicit a DNA damage response}

When an intrachromosomal DNA break occurs, it must be recognized as DNA damage to activate repair/recom- bination pathways, whose primary function is to repair the break. DSB repair can occur by NHEJ, which is able to join two chromosomal ends with no, or minimal, base-pairing at the junction. If a DSB is not repaired by NHEJ, 5'-to-3' resection of the DSB ends generates 3'ended ssDNA tails, which are channeled into different homology-dependent recombination pathways (for a review, see Krogh and Symington 2004).

In both yeast and human, generation of accidental DSBs triggers the activation of the DNA damage checkpoint pathway (Fig. 2A), whose primary purpose is to arrest the cell cycle in response to DNA damage, thereby coordinating cell cycle progression with DNA repair capacity (for reviews, see Longhese et al. 2006; Shiloh 2006). Key players in the DNA damage checkpoint response belong to a protein kinase family, including mammalian Ataxia Telangiectasia Mutated (ATM) and Ataxia Telangiectasia and Rad3-related (ATR), S. cerevisiae Tell and Mec1, and S. pombe Tel1 and Rad3 (for reviews, see Longhese et al. 2006; Shiloh 2006). Mec1 and Rad3 are more similar to ATR, whereas Tell is more similar to ATM. Both yeast Tell and human ATM appear to bind DNA through their interaction with the MRX and MRN complexes, respectively (Nakada et al. 2003; Falck et al. 2005). Rather than using MRX/MRN, Mec1, Rad3, and ATR function in a complex with Ddc2 (Paciotti et al. 2000), Rad26 (Edwards et al. 1999), and ATRIP (Cortez et al. 2001), respectively. Mec1/ATR ability to transmit and amplify the DNA damage signals is enhanced by a proliferating cell nuclear antigen (PCNA)like complex called Ddc1-Rad17-Mec3 in budding yeast, and Rad9-Rad1-Hus1 in both mammals and Schizosaccharomyces pombe, respectively (Majka et al. 2006). This complex is recruited to damaged DNA through a replication factor $\mathrm{C}$ (RF-C)-like complex, consisting of the four small RF-C subunits that interact with budding yeast $\operatorname{Rad} 24$, or its $S$. pombe and human ortholog Rad17.

Several lines of evidence indicate that the signaling event for DSB-induced checkpoint activation is the recruitment of the MRX/MRN complex to the break site (Fig. 2A), which occurs independently of any other DNA damage response protein examined so far (Lisby et al. 2004). Remarkably, MRX/MRN recognition of DSBs leads to the recruitment of Tell/ATM (Nakada et al. 2003; Falck et al. 2005; You et al. 2005). Because Tel1/ ATM signaling is up-regulated when MRX occupancy at DSBs is prolonged by the nonnull rad50s allele or the deletion of the SAE2 gene (Usui et al. 2001; Lisby et al. 2004; Morales et al. 2005; Clerici et al. 2006), this indicates that the loading of MRX/MRN to the DSBs initiates checkpoint activation. Notably, the checkpoint functions of Tell appear more furtive than those of ATM. In fact, Tell-deficient cells do not show obvious hypersensitivity to DNA-damaging agents and are not defective in checkpoint activation in response to a single HO-induced DSB, which depends primarily on Mec1 (Ira et al. 2004; Clerici et al. 2006; Mantiero et al. 2007). However, recent evidence indicates that Tell can activate the checkpoint response to DSBs independently of $\mathrm{Mec1}$, although its signaling activity becomes apparent 
A

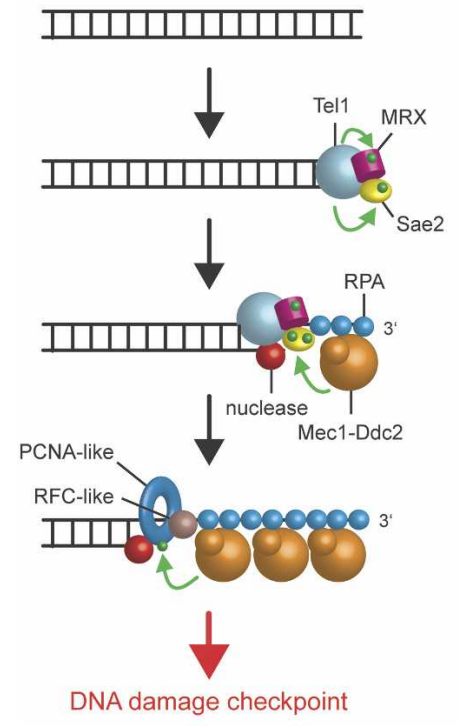

DSB
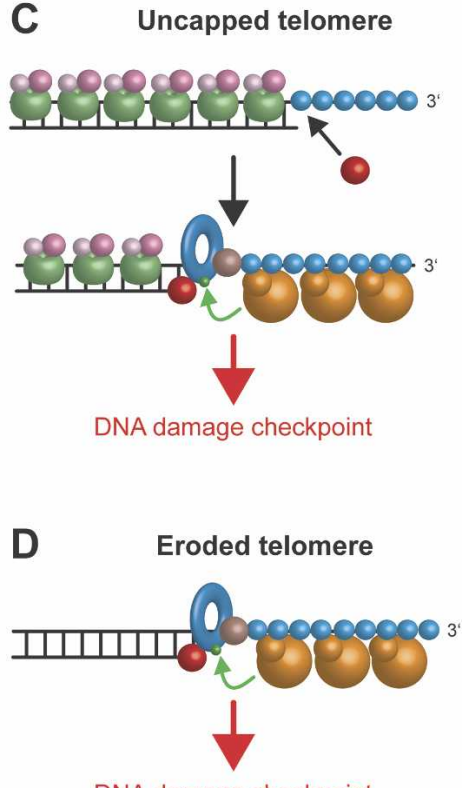

Figure 2. DNA damage response to DSBs and dysfunctional telomeres. (A) Intrachromosomal DSBs trigger a DNA damage checkpoint response. When a DSB occurs, the MRX complex and other factors localize to the unprocessed break. DSB recognition by MRX allows checkpoint activation by recruiting Tel1. Tell in turn phosphorylates Sae2, which is recruited to DSB ends independently of MRX. MRX, Sae2, and Tell contribute to resection of DSB ends by exonucleases to generate 3 '-ended ssDNA tails coated by RPA, which allow the loading of Mec1-Ddc2 and subsequent Mec1-dependent checkpoint activation. Mecl activation is also supported by independent loading of the PCNA-like Ddc1Rad17-Mec3 complex by Rad24-RFC. $|B|$ Full-length telomeres are protected from checkpoint activation. The presence of ssDNA- and dsDNA-binding proteins on fulllength chromosomal ends inhibits recruitment of MRX, RPA, nucleases, telomerase, and checkpoint proteins. $(C, D)$ Telomeres lose protection after loss of telomeric ssDNAand dsDNA-binding proteins (uncapped telomere) or telomerase (eroded telomere). $(C)$ In the absence of the ssDNA-binding protein Cdc13, telomerase recruitment is impaired, and nucleases can access the chromosome end. This leads to C-rich strand degradation and accumulation of RPA-bound ssDNA, which elicits activation of a Mec1-dependent DNA damage checkpoint response. $(D)$ RPAbound ssDNA accumulates at telomeres also after telomere erosion due to telomerase loss. The $S$. cerevisiae nomenclature is used. Green arrows indicate phosphorylation events. only in the presence of multiple DSBs (Mantiero et al. 2007). Tell ability to sense and transduce the DSB signal is disrupted when DSB ends are subjected to 5'-3' exonucleolytic degradation (Mantiero et al. 2007), suggesting that Tell/ATM and MRX/MRN are recruited to blunt or minimally processed DSB ends to initiate DSB signaling.

In both yeast and humans, the MRN-ATM and MRXTell complexes, once recruited to DSBs, also contribute to generate 3 '-ended ssDNA (Falck et al. 2005; Adams et al. 2006; Jazayeri et al. 2006; Myers and Cortez 2006; Mantiero et al. 2007), the critical intermediate structure recognized by the Mec1-Ddc2 and human ATR-ATRIP complexes (Fig. 2A; Zou and Elledge 2003). This implies that initiation of DSB resection is a critical step for the transition from Tell/ATM- to Mec1/ATR-dependent checkpoint activation.

Once DNA perturbations are sensed, the checkpoint signals are propagated through evolutionarily conserved protein kinases, which are called Rad53 and Chk1 in $S$. cerevisiae, and Chk2 and Chk1 in humans, respectively. Noteworthy, Rad53 and Chk1 activation is not governed by their simple interaction with Mec1 or Tel1, but requires a stepwise process. In particular, it has been pro- posed that the Rad9 protein acts first as an adaptor to mediate the interaction between Mec1 and Rad53 (Sweeney et al. 2005), and then as a scaffold to allow Rad53 autophosphorylation and activation (Gilbert et al. 2001).

\section{Telomere dysfunctions elicit a DNA damage response}

One of the primary functions of ssDNA- and dsDNAbinding telomeric proteins is to suppress checkpoint response, repair, and recombination at telomeres (Fig. 2B). When chromosome end protection fails, dysfunctional telomeres are targeted by the DNA repair and recombination apparatus. The outcomes of such events at telomeres range from the generation of chromosomal abnormalities, general hallmarks for cancer cells in humans, to permanent cell cycle arrest and cell death. NHEJ of two telomeres creates circular or dicentric chromosomes. Furthermore, illegitimate recombination could generate aberrant telomere length and extrachromosomal telomeric circles. Indeed, telomeric circles are found in Kluyveromyces lactis cells with capping deficiencies (Groff-Vindman et al. 2005; Cesare et al. 2007) as well as in $S$. cerevisiae, mouse, and human cells lacking functional telomerase /Cesare and Griffith 2004; 
Wang et al. 2004; Larrivee and Wellinger 2006). Finally, HR at t-loops can lead to sudden loss of telomeric DNA (Wang et al. 2004). In fact, if the 5 '-end of the telomere would pair with the displaced loop, this may generate a double Holliday Junction (dHJ), whose resolution would delete the whole loop, leaving a telomeric DNA circle and a drastically shortened telomere at the chromosome end.

In yeast, mice, and humans, telomeres that are stripped of the protective shelterin complex evoke a DNA damage response and may undergo repair attempts by HR or NHEJ. In fact, POT1 lack of function results in rapid loss of telomeric DNA, telomere fusions, aberrant $\mathrm{HR}$, chromosome segregation defects, increase in the amount of G-strand overhangs, and cell death in both fission yeast and vertebrates (Baumann and Cech 2001; Veldman et al. 2004; Hockemeyer et al. 2005; Yang et al. 2005; Churikov et al. 2006; He et al. 2006; Wu et al. 2006). In addition, budding yeast Rapl loss results in frequent fusions between telomeres by NHEJ (Pardo and Marcand 2005), and ligase IV-dependent chromosome fusions accumulate in $S$. pombe cells lacking Rap1 or Taz1 (Ferreira and Cooper 2001; Miller et al. 2005). In mammals, TRF2 protects telomeres by repressing both HR and NHEJ. In fact, in mice, the frequency of exchanges between sister telomeres increases when both TRF2 and Ku70 are absent (Celli et al. 2006). Moreover, a dramatic increase in telomere-telomere fusions has been associated with expression of a dominant-negative allele of TRF2 (van Steensel et al. 1998). Finally, a conditional knockout of TRF2 in mouse embryonic fibroblasts reveals an even more dramatic phenotype with virtually all telomeres engaged in end-to-end fusions (Celli and de Lange 2005). In both yeast and mammals, cells lacking DNA ligase IV or Ku70 display reduced ability to fuse telomeres after shelterin inhibition, indicating that these fusion events require the same factors as normal NHEJ (Ferreira and Cooper 2001; Smogorzewska et al. 2002; Mieczkowski et al. 2003; Celli and de Lange 2005). Because TRF2 can promote t-loop formation in vitro (Stansel et al. 2001), one possibility is that TRF2 blocks NHEJ by hiding the telomere ends in the t-loop structure that could block end-loading of Ku (Celli et al. 2006). However, human telomeres become fusogenic only upon loss of 12.8 double-stranded TTAGGG repeats (Capper et al. 2007), suggesting that telomere protection is still intact even on telomeres that are too short to form t-loops.

In mammals, NHEJ at telomeres requires the removal of the long telomeric 3' overhangs by the nucleotide excision repair endonuclease ERCC1/XPF, which cuts DNA duplexes adjacent to a $3^{\prime}$ ssDNA flap (Zhu et al. 2003). The absence of ERCC1/XPF in cells that have uncapped telomeres due to TRF2 inhibition leads to the generation of the so-called telomeric DNA-containing double minute chromosomes (TDMs), circular extrachromosomal elements, appearing as two closely positioned dots in metaphase. Presumably, these TDMs are generated through the recombination between the end of telomeres and interstitial telomere-related TTAGGGlike sequences, thus generating a terminally deleted chromosome and a circular product containing telomeric DNA (Zhu et al. 2003).

The lack of shelterin also leads to activation of the DNA damage checkpoint (Fig. 2C; for a review, see Viscardi et al. 2005). In S. cerevisiae, inactivation of the telomere end-binding protein $\mathrm{Cdc} 13$ leads to C-rich strand degradation and accumulation of very long ssDNA regions that extend into the nontelomeric DNA (Fig. 2C; Garvik et al. 1995; Zubko et al. 2004). This hallmark of telomere dysfunction activates a DNA damage checkpoint preventing anaphase entry, which requires Mec1, Ddc2, Rad9, Rad24, Ddc1, Mec3, Rad17, Rad53, and Chk1 (Garvik et al. 1995; Lydall and Weinert 1995).

In mammals, the loss of TRF2 activates the ATM-dependent pathway, leading to p53 up-regulation and p21mediated G1/S arrest (Karlseder et al. 1999; Celli and de Lange 2005). After inhibition of TRF2 or when telomeres become critically short, 53BP1, $\gamma$ - $\mathrm{H} 2 \mathrm{AX}$, the MRN complex, Rif1, and phosphorylated ATR and ATM accumulate at telomeres, thus forming the so-called telomere dysfunction-induced foci (TIFs) (Takai et al. 2003). TIFs are also generated when the shelterin components TIN2 or POT1 are inhibited (Kim et al. 2004; Hockemeyer et al. 2005). The consequences of TRF2 loss are exacerbated when the expression of its interacting protein Apollo is inhibited, suggesting that TRF2 works together with Apollo to protect chromosome termini (Lenain et al. 2006; van Overbeek and de Lange 2006).

A DNA damage response is also elicited in response to telomere erosion by inhibition of telomere replication (Fig. 2D). In S. cerevisiae, this response is mediated by Mec1-Ddc2 and by their accessory factors $\operatorname{Rad} 24$ and Ddc1-Rad17-Mec3 complex (Ijpma and Greider 2003). In contrast to what is observed in response to $c d c 13$-induced damage, where checkpoint activation is entirely Rad9-dependent, both Rad9 and Mrc1 are required to activate the checkpoint in telomerase-deficient cells (Ijpma and Greider 2003; Grandin and Charbonneau 2007). Because telomeric chromatin has the ability to form various unusual structures (heterochromatin-like, t-loop, and G-quadruplex structures), replication forks experience a physiological pausing and/or stalling whenever they reach telomeres (Ivessa et al. 2002; Makovets et al. 2004; Verdun and Karlseder 2006). Because Mrc1 mediates the response to replication blocks after treatment with the DNA synthesis inhibitor hydroxyurea (HU) (Alcasabas et al. 2001), inhibition of telomere replication might be recorded as a DNA replication stress, thus explaining Mrc1 activation. Mrc1 also contributes to protect uncapped telomeres from Exo1-dependent degradation, suggesting that telomere capping is intimately linked with DNA replication (Tsolou and Lydall 2007).

\section{Potential mechanisms for checkpoint inhibition at functional telomeres}

It is well known that accumulation of ssDNA at DSBs above a certain threshold invokes an ATR/Mec1-dependent DNA damage response (Lee et al. 1998; Zou and 
Elledge 2003). Although ssDNA overhangs are present at chromosomes ends, budding yeast telomeres transiently acquire long (50-100 bases) single-stranded G-tails only during a short time window in late $S$ phase (Wellinger et al. 1993). Thus, one possibility, at least in $S$. cerevisiae, is that ssDNA in the G-tails does not persist long enough to be detected by the checkpoint machinery. Mammalian telomeres have long single-stranded telomeric ends (Makarov et al. 1997). One elegant solution to establishing an inaccessible state of a telomere in mammals is the remodeling of linear DNA into t-loops, which can conceal the chromosome ends from being recognized by the DNA damage checkpoint (Fig. 1A, top). Although their role in t-loop formation has not yet been tested in vivo, shelterin components have DNA remodeling activities that are relevant for t-loop formation. In particular, purified TRF2 can remodel an artificial telomeric substrate into loops in vitro (Stansel et al. 2001). Interestingly, it has been recently shown that TRF2 generates positive supercoiling and condenses DNA (Amiard et al. 2007). This topological activity correlates with the ability to stimulate strand invasion, suggesting that TRF2 complexes, by constraining DNA around themselves in a right-handed conformation, can induce untwisting of the neighboring DNA, thereby favoring strand invasion (Amiard et al. 2007).

However, given that both $S$. cerevisiae and $S$. pombe telomeres are presumably too short to generate t-loops and that it is presently unclear whether all telomeres or only a subset of them adopt the t-loop conformation in other organisms, alternative mechanisms should exist to prevent telomeric single-stranded overhangs from eliciting a DNA damage response. The finding that inhibition of POT1 triggers an ATR-dependent checkpoint response (Lazzerini Denchi and de Lange 2007) suggests that POT1 inhibits ATR activation by blocking the recruitment of RPA to the single-stranded telomeric DNA (Fig. 1A, bottom; Lei et al. 2004, 2005; Kelleher et al. 2005). Similarly, the analysis of the mechanism by which $S$. cerevisiae TG repeats inhibit checkpoint signaling from the adjacent DSB has shown that Cdc13 binding to TG sequences at a newly formed DSB prevents Exol from binding to the DNA end, therefore inhibiting Exol-dependent degradation and RPA recruitment (Hirano and Sugimoto 2007). As a result, the TG sequences attenuate the Mec1-dependent checkpoint (Fig. 1B).

In any case, because even unprocessed DSBs can elicit a DNA damage response that depends primarily on MRX/MRN and ATM/Tel1 (Mantiero et al. 2007), protection of single-stranded telomeric overhangs may be insufficient to prevent a DNA damage response at telomeres. Consistent with this hypothesis, it has been shown that neither the presence of long 3 '-ended singlestranded overhangs nor t-loop formation is essential to prevent NHEJ-mediated ligation of human telomeric ends in vitro (Bae and Baumann 2007). Instead, a tandem array of 12 telomeric repeats is sufficient to impede illegitimate repair at nearby DNA ends (Bae and Baumann 2007). This suggests that full-length telomeres have acquired a structure that may physically hide the telomeric ends from DNA repair/recombination/checkpoint activities and telomerase. The existence of an anti-checkpoint activity has been demonstrated in S. cerevisiae, by virtue of its capacity to inhibit checkpoint activation from a DSB through adjacent telomeric sequences (Michelson et al. 2005). Although its precise molecular nature is unknown, the effect of this anti-checkpoint is exerted only in cis, suggesting that telomeres create a local protein environment that inhibits checkpoint signaling.

The telomeric anti-checkpoint activity may reside on shelterin, whose lack in both yeast and humans elicits a DNA damage response. Long arrays of Rap1 at fulllength $S$. cerevisiae telomeres protect them against nucleolytic attack and activation of the DNA damage checkpoint. In fact, by examining events at DNA breaks generated adjacent to either natural telomeric sequences or arrays of Rap1-binding sites that vary in length, it has been shown that Rap1 binding at long TG tracts inhibits recruitment of both Mre11 and Cdc13 (Negrini et al. 2007). Moreover, it prevents exonucleolytic resection and binding of both RPA and Mec1 to the telomeric ends (Fig. 1B; Negrini et al. 2007). In humans, attenuation of checkpoint signaling at telomeres may be achieved through the action of the shelterin component TRF2 (Fig. 1A, bottom), whose loss activates a checkpoint response that is primarily dependent on ATM (Lazzerini Denchi and de Lange 2007). Consistent with this hypothesis, biochemical fractionation and reconstitution experiments have shown that tandem array-dependent telomere protection is mediated by a complex containing human TRF2 and RAP1 (Bae and Baumann 2007).

How TRF2 prevents ATM activation is not yet clear. Because TRF2 binds to a region in ATM that contains Ser1981 (Karlseder et al. 2004), which in turn undergoes DNA damage-induced autophosphorylation in trans leading to ATM activation (Bakkenist and Kastan 2003), it has been suggested that TRF2 may block this activation. Because the abundance of shelterin at telomeres depends on the length of the duplex telomeric repeat array, the diminished loading of TRF2 and POT1 at critically short telomeres may relieve inhibition of the ATM and ATR kinases, resulting in checkpoint-mediated cell cycle arrest and inappropriate DNA repair at telomeres (Lazzerini Denchi and de Lange 2007).

Interestingly, removal of POT1 leads to an ATR-dependent DNA damage response in $\mathrm{Atm}^{-/-}$cells, suggesting that ATM is not required for the activation of ATR under these conditions (Lazzerini Denchi and de Lange 2007). This finding contrasts with the situation at irradiation- and HO-induced DSBs, where ATM and Tell signaling can promote activation of ATR and Mec1, respectively, possibly by stimulating the formation of ssDNA at the broken ends (Jazayeri et al. 2006; Mantiero et al. 2007).

\section{DNA repair/recombination and DNA damage checkpoint proteins are involved in telomere homeostasis}

Although one of the primary functions of telomeric proteins is to suppress both repair/recombination and 
checkpoint pathways, DNA repair/recombination and checkpoint proteins are found at functional telomeres each cell cycle and assist the telomere in assuming its proper structure and function.

\section{DNA repair/recombination proteins at telomeres}

Both human Ku70-Ku80 and ERCC1/XPF interact with components of the shelterin complex (Song et al. 2000; Chai et al. 2002; Zhu et al. 2003), suggesting that shelterin cooperates with them to regulate telomere length and protection. Consistent with this hypothesis, the $\mathrm{Ku} 70-\mathrm{Ku} 80$ heterodimer is involved in maintaining telomere length in S. cerevisiae, S. pombe, and humans, and this function appears to be distinct from its role in NHEJ (for a review, see Fisher and Zakian 2005). Yeast yku mutants have critically short telomeres with long G-tails that persist throughout the cell cycle (Gravel et al. 1998; Polotnianka et al. 1998). Because both the telomere length defects and the generation of long G-tails in a yku $\Delta$ mutant are suppressed by EXO1 disruption (Maringele and Lydall 2002; Bertuch and Lundblad 2004), the lack of telomere protection toward Exol and/or other nucleases in yku mutants may explain the generation of the observed constitutive overhangs. Notably, yKu proteins interact specifically with a stem-loop portion of TLC1 RNA in yeast cells (Peterson et al. 2001; Stellwagen et al. 2003), and this interaction is essential for Est2 telomere association in G1 (Fisher et al. 2004), indicating that $\mathrm{Ku}$ promotes telomere addition by targeting telomerase to chromosomal ends.

Although telomeres prevent chromosome fusions by $\mathrm{HR}$, the latter provides a telomerase-independent mechanism for maintaining telomeric repeats in some budding yeast mutants, in a few experimentally immortalized human cells, and in a fraction of cancer cells (Lundblad and Blackburn 1993; Muntoni and Reddel 2005). In fact, when $S$. cerevisiae telomeres become critically short in the absence of telomerase, cells experience progressive erosion of telomeric repeats and cease to divide (Lundblad and Szostak 1989). However, rare survivors emerge that use HR to maintain their telomeres (Lundblad and Blackburn 1993). Based on different genetic requirements and telomeric DNA rearrangements, two pathways for survivor generation have been identified. Both pathways require Rad52, but generation of type I survivors relies on proteins belonging to the Rad51 epistasis group, while type II survivor generation uses a Rad50-dependent amplification of the TG repeats (for a review, see Lundblad 2002). A characterization of telomeric DNA in telomerase- and capping-independent budding yeast survivors has revealed the presence of extrachromosomal circular DNA molecules that are probably recombination products (Larrivee and Wellinger 2006). Because HR relies on ssDNA $3^{\prime}$ overhangs to initiate strand invasion, initiation of survivor pathways should depend on generation of single-stranded G-tail overhangs. Consistent with this hypothesis, the exonuclease Exo1 is implicated in generating type I and type II yeast survivors (Maringele and Lydall 2004).
DNA damage checkpoint proteins at telomeres

Telomere structure and function depend on proteins known to be required for DNA damage checkpoint activation. In both yeast and human, the Tel1/ATM checkpoint kinase is found at telomeres during $S$ phase in an MRX/MRN-dependent manner (Verdun and Karlseder 2006; Hector et al. 2007; Sabourin et al. 2007). Tel1/ ATM contributes to maintain telomere length. In fact, ATM inhibition by caffeine treatment or MRN elimination leads to extended telomere exposure and telomere fusions in human cells (Bi et al. 2004; Ciapponi et al. 2004; Verdun et al. 2005; Foster et al. 2006). Moreover, both $S$. cerevisiae telomerase and Tell are needed to prevent telomeres from fusing to DSBs by NHEJ (Chan and Blackburn 2003). Tell inactivation in the absence of telomerase also increases the rate of gross chromosomal rearrangements, which are represented by NHEJ-mediated translocations and chromosome fusions (Pennaneach and Kolodner 2004). Finally, the lack of Tel1/ATM in $S$. cerevisiae, $S$. pombe, and human cells causes telomere shortening (Metcalfe et al. 1996; Dahlen et al. 1998; Matsuura et al. 1999; Ritchie et al. 1999). The telomere length defects of mre $11 \Delta$ and tel1s mutants are presumably due to a reduced frequency of telomerase-mediated elongation. In fact, $S$. cerevisiae cells lacking either Mre11 or Tell exhibit a reduced recruitment to short telomeres of both the telomerase catalytic subunit Est2 and its accessory protein Est1 (Goudsouzian et al. 2006), indicating that Tell and MRX promote telomerase recruitment at telomeres (Fig. 3A). Recent data also implicate Tell in increasing telomerase repeat addition processivity at critically short telomeres (Chang et al. 2007).

Both $S$. cerevisiae and $S$. pombe cells rely on Mec1/ Rad3 to maintain short but stable telomeres in the absence of Tel1, suggesting that the function of Mec1/ATR at telomeres is redundant with or masked by Tell and MRX in normal cells. Concomitant inactivation of both Tell/ATM and Mec1/ATR kinases in S. cerevisiae and $S$. pombe leads to chromosome self-circularization and complete loss of telomeric sequences, similar to that seen in cells lacking active telomerase (Naito et al. 1998; Ritchie et al. 1999; Nakamura et al. 2002). Moreover, as observed with TEL1 inactivation, the lack of RAD50 in a mec1 mutant leads to telomere erosion (Ritchie et al. 1999; Ritchie and Petes 2000).

Tell/ATM (and possibly Mec1/ATR) may affect multiple aspects of telomere homeostasis through phosphorylation of telomeric targets. Recent work in $S$. cerevisiae has identified serine residues in Cdc13 that are phosphorylated by Tell and Mec1 (Tseng et al. 2006) in a domain of the protein known to be involved in telomerase recruitment (Pennock et al. 2001; Bianchi et al. 2004). This suggests that Tell-dependent phosphorylation is responsible for rendering $\mathrm{Cdc} 13$ competent for interaction with Est1 preferentially at short telomeres (Fig. 3A). Because short telomeres are preferentially elongated by telomerase (Teixeira et al. 2004) and Tell mainly associates with short telomeres and mediates telomerase binding to them (Hector et al. 2007; Sabourin 
A S. cerevisiae

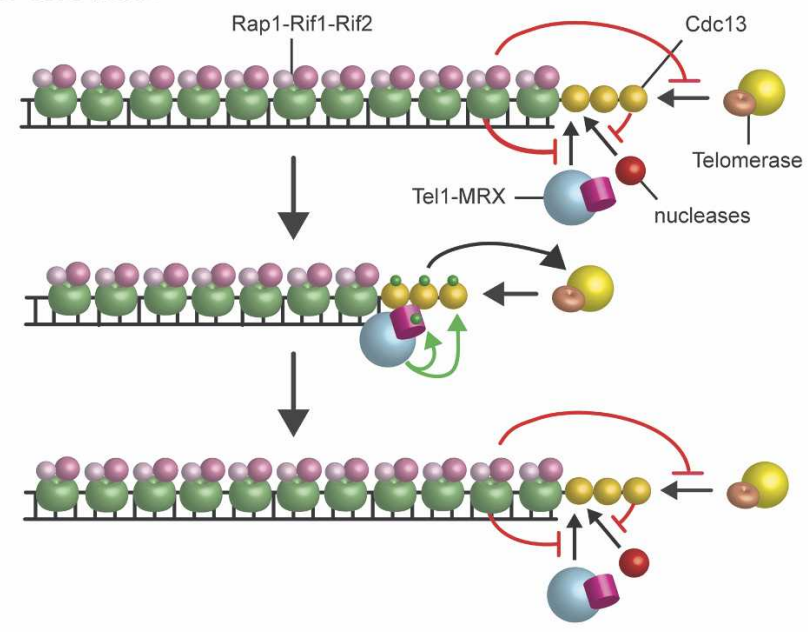

B H. sapiens

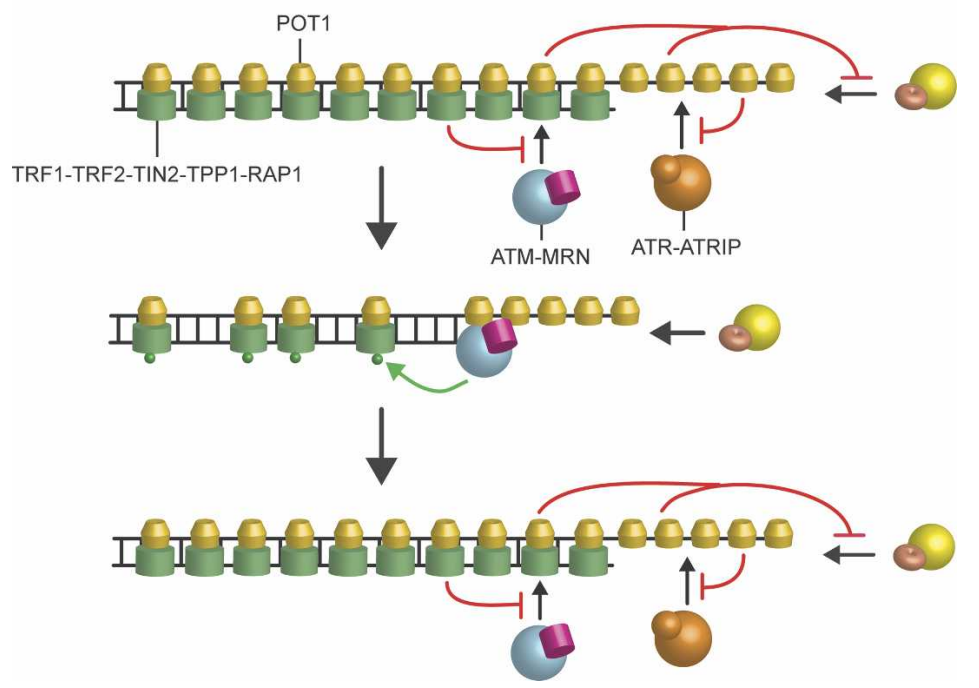

Figure 3. Contribution of DNA damage checkpoint proteins to telomere homeostasis regulation. (A) In $S$. cerevisiae, the access at full-length telomeres of telomerase, Tell-MRX, and nucleases is inhibited. As telomere length declines, MRX and Tell promote the recruitment of telomerase at telomeres by phosphorylating the ssDNA-binding protein $\mathrm{Cdc} 13$, which mediates telomerase recruitment. $(B)$ In humans, MRN and ATM promote telomerase-dependent telomere elongation by phosphorylating TRF1 on shortened telomeres. Phosphorylated TRF1 dissociates from telomeres, thus promoting telomerase access. In both yeast and humans, the subsequent telomere elongation increases the loading on telomeres of Rap1-Rif1-Rif2 and shelterin proteins, respectively, which can in turn block Tel1/ATM from acting, thus resulting in telomere reprotection. Green arrows indicate phosphorylation events. et al. 2007), these data point to telomere length-dependent binding of Tell to telomeres as a critical step in the regulation of telomerase association with telomeres in $S$ phase. In any case, it is likely that other substrates exist and their phosphorylation may mediate the different aspects of Tell function.

Both human TRF1 and TRF2 undergo ATM-dependent phosphorylation in response to ionizing radiation (Kishi et al. 2001; Tanaka et al. 2005). Moreover, ATM- and MRN-mediated TRF1 phosphorylation appears to negatively regulate TRF1 association with telomeres (Wu et al. 2007). This suggests that MRN promotes telomerasedependent telomere elongation by engaging ATM at telomeres, which in turn phosphorylates TRF1. Phosphorylated TRF1 dissociates from telomeres, thus promoting telomerase access to the ends of telomeres (Fig. 3B).

The connections between telomeres and the DNA damage checkpoint are not limited to Mec1/ATR and Tell/ATM. Telomere length maintenance in $S$. cerevisiae is also influenced by the checkpoint kinase Rad53 and by the Rad17-Mec3-Ddc1 complex (Longhese et al. 2000). Notably, this role for Rad17-Mec3-Ddc1 is evolutionarily conserved. Caenorhabditis elegans strains lacking HUS-1 or MRT-2, the functional orthologs of $S$. cerevisiae Mec3 and Rad17, respectively, display progressive telomere shortening and loss of germline immortality (Ahmed and Hodgkin 2000; Hofmann et al. 2002), and mutations in a similar set of genes affect telomere length in fission yeast (Dahlen et al. 1998; Nakamura et al. 2002). Moreover, the human Rad9-Hus1Rad1 complex is constitutively associated with telomeres in both human and mouse cells, and the lack of Hus 1 leads to a dramatic telomere shortening (Francia et al. 2006).

\section{Functional telomeres can generate temporally limited DNA damage responses}

It is well established that the natural chromosome ends need to be protected from inappropriate repair/recombi- 
nation and checkpoint events, so it seems paradoxical that several proteins involved in DNA repair and checkpoints localize at telomeres and are required to maintain telomere length. This implies that the difference between a DNA break and a telomere is less pronounced than previously assumed, suggesting a temporally limited window where telomeres are detected as DSBs. Because t-loop formation and shelterin capping function can be temporarily lost after the passage of a replication fork, and native telomeres are susceptible to Clb-CDK1dependent nucleolytic processing in late S/G2 (Frank et al. 2006; Vodenicharov and Wellinger 2006), functional telomeres may be recognized as DNA breaks during and/ or soon after their replication.

It has been recently shown that $S$. cerevisiae telomeres behave similarly to intrachromosomal DSBs when they are suitable for elongation (Fig. 4; Viscardi et al. 2003, 2007). In fact, a prolonged expansion of either a single or multiple shortened telomeres causes the activation of an MRX-dependent checkpoint, suggesting that telomeres can be perceived and treated as DSBs in a window of time during their replication. MRX binding at short telomeres is the signaling event for checkpoint activation and is sufficient to activate the checkpoint independently of telomere elongation (Viscardi et al. 2007). These results imply that only telomeres that become susceptible to be bound by MRX, and therefore suitable for elongation, can be recognized as DSBs by the checkpoint machinery. Indeed, MRX is recruited to native telomeres in late $S$ phase (Zhu et al. 2000; Takata et al. 2005), and only telomeres with short TG tracts are avidly bound by
MRX, as well as by the telomerase enzyme (Negrini et al. 2007; Viscardi et al. 2007), suggesting that under unperturbed conditions, only S-phase telomeres are potentially detectable as DSBs by the checkpoint machinery. However, the yeast telomerase enzyme only acts on short telomeres within one cell cycle, and the rate of telomere elongation appears limited to a few base pairs per generation (Teixeira et al. 2004). This limitation may prevent unscheduled checkpoint activation during an unperturbed $\mathrm{S}$ phase.

Generation of transient checkpoint signals at S-phase telomeres appears to be conserved in humans, where functional telomeres have been shown to undergo structural changes that elicit a DNA damage response during or after DNA replication (Verdun et al. 2005; Verdun and Karlseder 2006). By studying the association of checkpoint and repair proteins at elongating telomeres in primary human fibroblasts, it has been shown that a DNA damage response depending primarily on ATR is elicited before telomere replication is completed. After replication, telomeres attract the ATM and the HR machineries (Verdun and Karlseder 2006). Both ATR and ATM recruitment follow the localization of MRN. Because ATR recognizes ssDNA potentially due to replication fork pausing and/or stalling, whereas ATM is thought to recognize DSBs, this suggests that there are at least two distinct DNA damage signals triggered at telomeres during and after replication, respectively. Notably, degradation of MRN, as well as inhibition of ATM, leads to telomere dysfunction, suggesting that a localized DNA damage response at telomeres after replication is essen-
Figure 4. A model for the generation of transient DNA damage signals at functional telomeres. During the G1 cell cycle phase, neither short nor fulllength telomeres are susceptible to be elongated by telomerase. They are also inert for processing events by nucleases. After completion of DNA replication in late $S$ phase and during the ensuing G2 phase, telomeres become susceptible to Clb-CDK1-dependent nucleolytic processing, which can generate RPA-coated ssDNA. During this time, telomeres share many features with DSBs. Telomeres with short TG tracts become preferentially suitable to be processed and bound by MRX. RPA-coated ssDNA generation and telomere-bound MRX can activate a transient Mec1- and Tell-dependent checkpoint, which in turn promotes telomere elongation by phosphorylating Cdc13. Telomere elongation increases the amount of proteins bound to TG tracts, and this change blocks telomerase and Mec1/Tell recruitment. A functional cap could be reassembled in the next G1, when Clb-CDK1 activity is low. Green arrows indicate phosphorylation events.

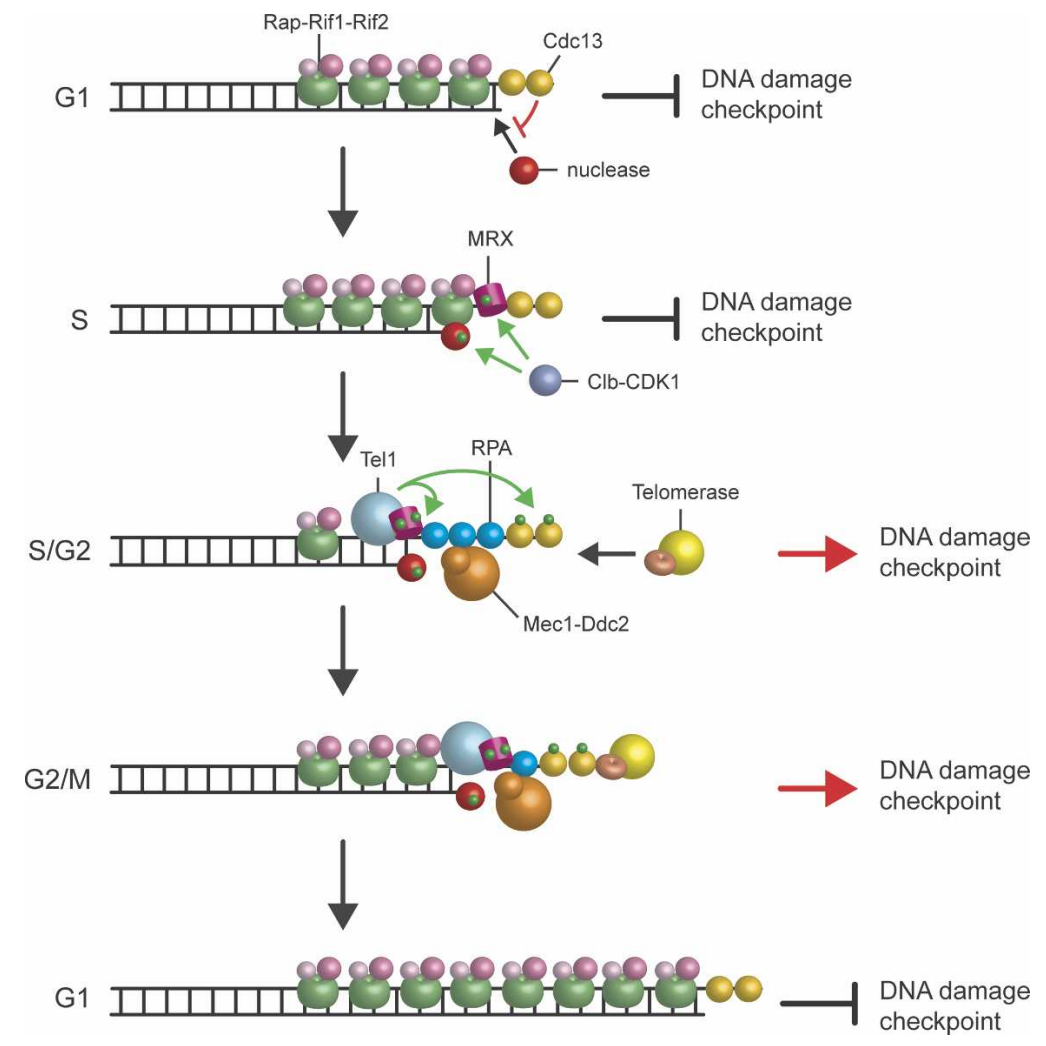


tial to re-establish chromosome end structure /Verdun et al. 2005). Once telomeric proteins assemble at singleand double-stranded ends, they may inhibit MRN-ATM, thus enforcing telomere identity.

\section{Conclusions}

In summary, our understanding of the molecular mechanisms ensuring chromosome end maintenance and identity has substantially increased in the past decade. ssDNA- and dsDNA-binding proteins (shelterin) shape chromosome ends and ensure their identity. These proteins regulate telomerase recruitment and protect the chromosome ends from being sensed as DSBs by the DNA damage checkpoint and repair/recombination machineries. However, the difference between telomeres and DSBs are less defined than previously assumed. In fact, proteins involved in DNA repair and DNA damage checkpoint are thought to assist shelterin functions. At the same time, shelterin must control both the actions and the persistence of these proteins at telomeric ends, because some of them have the potentiality to destroy them.

These insights also raise many new questions. For example, what aspects of shelterin functions might be assisted by ATM/ATR and MRN/MRX remains to be determined, and the identification of the telomeric components targeted by ATM/ATR and MRN/MRX could provide many insights into this question. Another major challenge will be to establish the role of the checkpoint proteins in ensuring telomere identity/maintenance, and the molecular mechanism controlling telomerase accessibility to the telomere. Moreover, apart from the identification of additional DNA repair/checkpoint factors acting at normal and/or dysfunctional telomeres, an important open question is the nature of the telomere signals that trigger a checkpoint response. Due to the critical role of both DNA damage checkpoints and telomere homeostasis in maintaining genetic stability and in counteracting cancer development, the knowledge of their interconnections is essential for our understanding of these key cellular controls.

\section{Acknowledgments}

We thank V. Viscardi, D. Bonetti, and G. Lucchini for critical reading of the manuscript, and all the members of the laboratory for useful discussions and criticisms. Studies in the laboratory were supported by grants from Associazione Italiana per la Ricerca sul Cancro, Fondazione CARIPLO, and Cofinanziamento 2005 MIUR/Università di Milano-Bicocca. We apologize to all authors whose publications have not been cited due to space limitation.

\section{References}

Adams, K.E., Medhurst, A.L., Dart, D.A., and Lakin, N.D. 2006. Recruitment of ATR to sites of ionising radiation-induced DNA damage requires ATM and components of the MRN protein complex. Oncogene 25: 3894-3904.

Ahmed, S. and Hodgkin, J. 2000. MRT-2 checkpoint protein is required for germline immortality and telomere replication in C. elegans. Nature 403: 159-164.

Alcasabas, A.A., Osborn, A.J., Bachant, J., Hu, F., Werler, P.J., Bousset, K., Furuya, K., Diffley, J.F., Carr, A.M., and Elledge, S.J. 2001. Mrc1 transduces signals of DNA replication stress to activate Rad53. Nat. Cell Biol. 3: 958-965.

Amiard, S., Doudeau, M., Pinte, S., Poulet, A., Lenain, C., Faivre-Moskalenko, C., Angelov, D., Hug, N., Vindigni, A., Bouvet, P., et al. 2007. A topological mechanism for TRF2enhanced strand invasion. Nat. Struct. Mol. Biol. 14: 147154.

Aylon, Y. and Kupiec, M. 2005. Cell cycle-dependent regulation of double-strand break repair: A role for the CDK. Cell Cycle 4: 259-261.

Bae, N.S. and Baumann, P. 2007. A RAP1/TRF2 complex inhibits nonhomologous end-joining at human telomeric DNA ends. Mol. Cell 26: 323-334.

Bakkenist, C.J. and Kastan, M.B. 2003. DNA damage activates ATM through intermolecular autophosphorylation and dimer dissociation. Nature 421: 499-506.

Baumann, P. and Cech, T.R. 2001. Pot1, the putative telomere end-binding protein in fission yeast and humans. Science 292: 1171-1175.

Bertuch, A.A. and Lundblad, V. 2004. EXO1 contributes to telomere maintenance in both telomerase-proficient and telomerase-deficient Saccharomyces cerevisiae. Genetics 166: 1651-1659.

Bi, X., Wei, S.C., and Rong, Y.S. 2004. Telomere protection without a telomerase: The role of ATM and Mrell in Drosophila telomere maintenance. Curr. Biol. 14: 13481353.

Bianchi, A. and Shore, D. 2007. Increased association of telomerase with short telomeres in yeast. Genes \& Dev. 21: 17261730.

Bianchi, A., Negrini, S., and Shore, D. 2004. Delivery of yeast telomerase to a DNA break depends on the recruitment functions of Cdc13 and Est1. Mol. Cell 16: 139-146.

Bilaud, T., Brun, C., Ancelin, K., Koering, C.E., Laroche, T., and Gilson, E. 1997. Telomeric localization of TRF2, a novel human telobox protein. Nat. Genet. 17: 236-239.

Broccoli, D., Smogorzewska, A., Chong, L., and de Lange, T. 1997. Human telomeres contain two distinct Myb-related proteins, TRF1 and TRF2. Nat. Genet. 17: 231-235.

Capper, R., Britt-Compton, B., Tankimanova, M., Rowson, J., Letsolo, B., Man, S., Haughton, M., and Baird, D.M. 2007. The nature of telomere fusion and a definition of the critical telomere length in human cells. Genes \& Dev. 21: 2495 2508.

Celli, G.B. and de Lange, T. 2005. DNA processing is not required for ATM-mediated telomere damage response after TRF2 deletion. Nat. Cell Biol. 7: 712-718.

Celli, G.B., Lazzerini Denchi, E., and de Lange, T. 2006. Ku70 stimulates fusion of dysfunctional telomeres yet protects chromosome ends from homologous recombination. Nat. Cell Biol. 8: 885-890.

Cesare, A.J. and Griffith, J.D. 2004. Telomeric DNA in ALT cells is characterized by free telomeric circles and heterogeneous t-loops. Mol. Cell. Biol. 24: 9948-9957.

Cesare, A.J., Groff-Vindman, C., Compton, S.A., McEachern, M.J., and Griffith, J.D. 2007. T-loops and homologous recombination dependent t-circles in a Kluyveromyces lactis telomere mutant strain. Mol. Cell. Biol. doi: 10.1128/MCB.0112207.

Chai, W., Ford, L.P., Lenertz, L., Wright, W.E., and Shay, J.W. 
2002. Human Ku70/80 associates physically with telomerase through interaction with hTERT. J. Biol. Chem. 277: 47242-47247.

Chai, W., Du, Q., Shay, J.W., and Wright, W.E. 2006a. Human telomeres have different overhang sizes at leading versus lagging strands. Mol. Cell 21: 427-435.

Chai, W., Sfeir, A.J., Hoshiyama, H., Shay, J.W., and Wright, W.E. 2006b. The involvement of the Mre11/Rad50/Nbs1 complex in the generation of G-overhangs at human telomeres. EMBO Rep. 7: 225-230.

Chan, S.W. and Blackburn, E.H. 2003. Telomerase and ATM/ Tellp protect telomeres from nonhomologous end joining. Mol. Cell 11: 1379-1387.

Chandra, A., Hughes, T.R., Nugent, C.I., and Lundblad, V. 2001. Cdc13 both positively and negatively regulates telomere replication. Genes \& Dev. 15: 404-414.

Chang, M., Arneric, M., and Lingner, J. 2007. Telomerase repeat addition processivity is increased at critically short telomeres in a Tell-dependent manner in Saccharomyces cerevisiae. Genes \& Dev. 21: 2485-2494.

Chong, L., van Steensel, B., Broccoli, D., Erdjument-Bromage, H., Hanish, J., Tempst, P., and de Lange, T. 1995. A human telomeric protein. Science 270: 1663-1667.

Churikov, D., Wei, C., and Price, C.M. 2006. Vertebrate POT1 restricts $\mathrm{G}$-overhang length and prevents activation of a telomeric DNA damage checkpoint but is dispensable for overhang protection. Mol. Cell. Biol. 26: 6971-6982.

Ciapponi, L., Cenci, G., Ducau, J., Flores, C., Johnson-Schlitz, D., Gorski, M.M., Engels, W.R., and Gatti, M. 2004. The Drosophila Mre11/Rad50 complex is required to prevent both telomeric fusions and chromosome breakage. Curr. Biol. 14: 1360-1366.

Clerici, M., Mantiero, D., Lucchini, G., and Longhese, M.P. 2006. The Saccharomyces cerevisiae Sae2 protein negatively regulates DNA damage checkpoint signalling. EMBO Rep. 7: 212-218.

Conrad, M.N., Wright, J.H., Wolf, A.J., and Zakian, V.A. 1990. RAP1 protein interacts with yeast telomeres in vivo: Overproduction alters telomere structure and decreases chromosome stability. Cell 63: 739-750.

Cooper, J.P., Nimmo, E.R., Allshire, R.C., and Cech, T.R. 1997. Regulation of telomere length and function by a Myb-domain protein in fission yeast. Nature 385: 744-747.

Cortez, D., Guntuku, S., Qin, J., and Elledge, S.J. 2001. ATR and ATRIP: Partners in checkpoint signalling. Science 294: 1713-1716.

Court, R., Chapman, L., Fairall, L., and Rhodes, D. 2005. How the human telomeric proteins TRF1 and TRF2 recognize telomeric DNA: A view from high-resolution crystal structures. EMBO Rep. 6: 39-45.

Dahlen, M., Olsson, T., Kanter-Smoler, G., Ramne, A., and Sunnerhagen, P. 1998. Regulation of telomere length by checkpoint genes in Schizosaccharomyces pombe. Mol. Biol. Cell 9: 611-621.

de Lange, T. 2005. Shelterin: The protein complex that shapes and safeguards human telomeres. Genes \& Dev. 19: 21002110.

Diede, S.J. and Gottschling, D.E. 2001. Exonuclease activity is required for sequence addition and Cdc13p loading at a de novo telomere. Curr. Biol. 11: 1336-1340.

Dionne, I. and Wellinger, R.J. 1998. Processing of telomeric DNA ends requires the passage of a replication fork. Nucleic Acids Res. 26: 5365-5371.

Edwards, R.J., Bentley, N.J., and Carr, A.M. 1999. A Rad3-Rad26 complex responds to DNA damage independently of other checkpoint proteins. Nat. Cell Biol. 1: 393-398.
Falck, J., Coates, J., and Jackson, S.P. 2005. Conserved modes of recruitment of ATM, ATR and DNA-PKcs to sites of DNA damage. Nature 434: 605-611.

Ferreira, M.G. and Cooper, J.P. 2001. The fission yeast Taz1 protein protects chromosomes from Ku-dependent end-toend fusions. Mol. Cell 7: 55-63.

Fisher, T.S. and Zakian, V.A. 2005. Ku: A multifunctional protein involved in telomere maintenance. DNA Repair (Amst.) 4: 1215-1226.

Fisher, T.S., Taggart, A.K., and Zakian, V.A. 2004. Cell cycledependent regulation of yeast telomerase by Ku. Nat. Struct. Mol. Biol. 11: 1198-1205.

Foster, S.S., Zubko, M.K., Guillard, S., and Lydall, D. 2006. MRX protects telomeric DNA at uncapped telomeres of budding yeast cdc13-1 mutants. DNA Repair (Amst.) 5: 840851.

Francia, S., Weiss, R.S., Hande, M.P., Freire, R., and d'Adda di Fagagna, F. 2006. Telomere and telomerase modulation by the mammalian Rad9/Rad1/Hus1 DNA-damage-checkpoint complex. Curr. Biol. 16: 1551-1558.

Frank, C.J., Hyde, M., and Greider, C.W. 2006. Regulation of telomere elongation by the cyclin-dependent kinase CDK1. Mol. Cell 24: 423-432.

Gao, H., Cervantes, R.B., Mandell, E.K., Otero, J.H., and Lundblad, V. 2007. RPA-like proteins mediate yeast telomere function. Nat. Struct. Mol. Biol. 14: 208-214.

Garvik, B., Carson, M., and Hartwell, L.L. 1995. Single-stranded DNA arising at telomeres in $c d c 13$ mutants may constitute a specific signal for the RAD9 checkpoint. Mol. Cell. Biol. 15: 6128-6138.

Gilbert, C.S., Green, C.M., and Lowndes, N.F. 2001. Budding yeast Rad9 is an ATP-dependent Rad53 activating machine. Mol. Cell 8: 129-136.

Gilson, E. and Geli, V. 2007. How telomeres are replicated. Nat. Rev. Mol. Cell Biol. 8: 825-838.

Goudsouzian, L.K., Tuzon, C.T., and Zakian, V.A. 2006. S. cerevisiae Tellp and Mre11p are required for normal levels of Est1p and Est2p telomere association. Mol. Cell 24: 603 610.

Grandin, N. and Charbonneau, M. 2007. Mrc1, a non-essential DNA replication protein, is required for telomere end protection following loss of capping by Cdc13, Yku or telomerase. Mol. Genet. Genomics 277: 685-699.

Grandin, N., Reed, S.I., and Charbonneau, M. 1997. Stn1, a new Saccharomyces cerevisiae protein, is implicated in telomere size regulation in association with Cdc13. Genes \& Dev. 11: 512-527.

Grandin, N., Damon, C., and Charbonneau, M. 2001. Ten1 functions in telomere end protection and length regulation in association with Stn 1 and Cdc13. EMBO J. 20: 1173 1183.

Gravel, S., Larrivee, M., Labrecque, P., and Wellinger, R.J. 1998. Yeast $\mathrm{Ku}$ as a regulator of chromosomal DNA end structure. Science 280: 741-744.

Greider, C.W. and Blackburn, E.H. 1985. Identification of a specific telomere terminal transferase activity in Tetrahymena extracts. Cell 43: 405-413.

Griffith, J.D., Comeau, L., Rosenfield, S., Stansel, R.M., Bianchi, A., Moss, H., and de Lange, T. 1999. Mammalian telomeres end in a large duplex loop. Cell 97: 503-514.

Groff-Vindman, C., Cesare, A.J., Natarajan, S., Griffith, J.D., and McEachern, M.J. 2005. Recombination at long mutant telomeres produces tiny single- and double-stranded telomeric circles. Mol. Cell. Biol. 25: 4406-4412.

Hardy, C.F., Sussel, L., and Shore, D. 1992. A Rap1-interacting protein involved in silencing and telomere length regulation. 
Genes \& Dev. 6: 801-814.

He, H., Multani, A.S., Cosme-Blanco, W., Tahara, H., Ma, J., Pathak, S., Deng, Y., and Chang, S. 2006. POT1b protects telomeres from end-to-end chromosomal fusions and aberrant homologous recombination. EMBO J. 25: 5180-5190.

Hector, R.E., Shtofman, R.L., Ray, A., Chen, B.R., Nyun, T., Berkner, K.L., and Runge, K.W. 2007. Tellp preferentially associates with short telomeres to stimulate their elongation. Mol. Cell 27: 851-858.

Hirano, Y. and Sugimoto, K. 2007. Cdc13 telomere capping decreases Mecl association but does not affect Tell association with DNA ends. Mol. Biol. Cell 18: 2026-2036.

Hockemeyer, D., Sfeir, A.J., Shay, J.W., Wright, W.E., and de Lange, T. 2005. POT1 protects telomeres from a transient DNA damage response and determines how human chromosomes end. $E M B O$ I. 20: 2667-2678.

Hofmann, E.R., Milstein, S., Boulton, S.J., Ye, M., Hofmann, J.J., Stergiou, L., Gartner, A., Vidal, M., and Hengartner, M.O. 2002. Caenorhabditis elegans HUS-1 is a DNA damage checkpoint protein required for genome stability and EGL1-mediated apoptosis. Curr. Biol. 12: 1908-1918.

Houghtaling, B.R., Cuttonaro, L., Chang, W., and Smith, S. 2004. A dynamic molecular link between the telomere length regulator TRF1 and the chromosome end protector TRF2. Curr. Biol. 14: 1621-1631.

Hug, N. and Lingner, J. 2006. Telomere length homeostasis. Chromosoma 115: 413-425.

Ijpma, A.S. and Greider, C.W. 2003. Short telomeres induce a DNA damage response in Saccharomyces cerevisiae. Mol. Biol. Cell 14: 987-1001.

Ira, G., Pellicioli, A., Balijja, A., Wang, X., Fiorani, S., Carotenuto, W., Liberi, G., Bressan, D., Wan, L., Hollingsworth, N.M., et al. 2004. DNA end resection, homologous recombination and DNA damage checkpoint activation require CDK1. Nature 431: 1011-1017.

Ivanov, E.L., Sugawara, N., White, C.I., Fabre, F., and Haber, J.E. 1994. Mutations in XRS2 and RAD50 delay but do not prevent mating-type switching in Saccharomyces cerevisiae. Mol. Cell. Biol. 14: 3414-3425.

Ivessa, A.S., Zhou, J.Q., Schulz, V.P., Monson, E.K., and Zakian, V.A. 2002. Saccharomyces Rrm3p, a 5' to 3' DNA helicase that promotes replication fork progression through telomeric and subtelomeric DNA. Genes \& Dev. 16: 1383-1396.

Jacob, N.K., Lescasse, R., Linger, B.R., and Price, C.M. 2007. Tetrahymena POT1a regulates telomere length and prevents activation of a cell cycle checkpoint. Mol. Cell. Biol. 27: 1592-1601.

Jazayeri, A., Falck, J., Lukas, C., Bartek, J., Smith, G.C., Lukas, J., and Jackson, S.P. 2006. ATM- and cell cycle-dependent regulation of ATR in response to DNA double-strand breaks. Nat. Cell Biol. 8: 37-45.

Kanoh, J. and Ishikawa, F. 2001. spRap1 and spRif1, recruited to telomeres by Taz1, are essential for telomere function in fission yeast. Curr. Biol. 11: 1624-1630.

Karlseder, J., Broccoli, D., Dai, Y., Hardy, S., and de Lange, T. 1999. p53- and ATM-dependent apoptosis induced by telomeres lacking TRF2. Science 283: 1321-1325.

Karlseder, J., Hoke, K., Mirzoeva, O.K., Bakkenist, C., Kastan, M.B., Petrini, J.H., and de Lange, T. 2004. The telomeric protein TRF2 binds the ATM kinase and can inhibit the ATM-dependent DNA damage response. PLoS Biol. 2: E240. doi: 10.1371/journal.pbio.0020240.

Kelleher, C., Kurth, I., and Lingner, J. 2005. Human protection of telomeres 1 (POT1) is a negative regulator of telomerase activity in vitro. Mol. Cell. Biol. 25: 808-818.

Kim, S.H., Kaminker, P., and Campisi, J. 1999. TIN2, a new regulator of telomere length in human cells. Nat. Genet. 23: 405-412.

Kim, S.H., Beausejour, C., Davalos, A.R., Kaminker, P., Heo, S.J., and Campisi, J. 2004. TIN2 mediates functions of TRF2 at human telomeres. J. Biol. Chem. 279: 43799-43804.

Kishi, S., Zhou, X.Z., Ziv, Y., Khoo, C., Hill, D.E., Shiloh, Y., and Lu, K.P. 2001. Telomeric protein Pin2/TRF1 as an important ATM target in response to double strand DNA breaks. J. Biol. Chem. 276: 29282-29291.

Krogh, B.O. and Symington, L.S. 2004. Recombination proteins in yeast. Annu. Rev. Genet. 38: 233-271.

Kyrion, G., Boakye, K.A., and Lustig, A.J. 1992. C-terminal truncation of RAP1 results in the deregulation of telomere size, stability, and function in Saccharomyces cerevisiae. Mol. Cell. Biol. 12: 5159-5173.

Larrivee, M. and Wellinger, R.J. 2006. Telomerase- and cappingindependent yeast survivors with alternate telomere states. Nat. Cell Biol. 8: 741-747.

Larrivee, M., LeBel, C., and Wellinger, R.J. 2004. The generation of proper constitutive G-tails on yeast telomeres is dependent on the MRX complex. Genes \& Dev. 18: 1391-1396.

Lazzerini Denchi, E. and de Lange, T. 2007. Protection of telomeres through independent control of ATM and ATR by TRF2 and POT1. Nature 448: 1068-1071.

Lee, S.E., Moore, J.K., Holmes, A., Umezu, K., Kolodner, R.D., and Haber, J.E. 1998. Saccharomyces Ku70, Mre11/Rad50 and RPA proteins regulate adaptation to G2/M arrest after DNA damage. Cell 94: 399-409.

Lei, M., Podell, E.R., and Cech, T.R. 2004. Structure of human POT1 bound to telomeric single-stranded DNA provides a model for chromosome end-protection. Nat. Struct. Mol. Biol. 11: 1223-1229.

Lei, M., Zaug, A.J., Podell, E.R., and Cech, T.R. 2005. Switching human telomerase on and off with hPOT1 protein in vitro. J. Biol. Chem. 280: 20449-20456.

Lenain, C., Bauwens, S., Amiard, S., Brunori, M., Giraud-Panis, M.J., and Gilson, E. 2006. The Apollo 5' exonuclease functions together with TRF2 to protect telomeres from DNA repair. Curr. Biol. 16: 1303-1310.

Levy, D.L. and Blackburn, E.H. 2004. Counting of Riflp and Rif2p on Saccharomyces cerevisiae telomeres regulates telomere length. Mol. Cell. Biol. 24: 10857-10867.

Li, B. and de Lange, T. 2003. Rap1 affects the length and heterogeneity of human telomeres. Mol. Biol. Cell 14: 5060 5068.

Li, B., Oestreich, S., and de Lange, T. 2000. Identification of human Rap1: Implications for telomere evolution. Cell 101: 471-483.

Li, B., Espinal, A., and Cross, G.A. 2005. Trypanosome telomeres are protected by a homologue of mammalian TRF2. Mol. Cell. Biol. 25: 5011-5021.

Lingner, J., Cooper, J.P., and Cech, T.R. 1995. Telomerase and DNA end replication: No longer a lagging strand problem? Science 269: 1533-1534.

Lisby, M., Barlow, J.H., Burgess, R.C., and Rothstein, R. 2004. Choreography of the DNA damage response: Spatiotemporal relationships among checkpoint and repair proteins. Cell 118: 699-713.

Liu, D., O'Connor, M.S., Qin, J., and Songyang, Z. 2004. Telosome, a mammalian telomere-associated complex formed by multiple telomeric proteins. J. Biol. Chem. 279: 5133851342.

Liu, L., Bailey, S.M., Okuka, M., Munoz, P., Li, C., Zhou, L., Wu, C., Czerwiec, E., Sandler, L., Seyfang, A., et al. 2007. Telomere lengthening early in development. Nat. Cell Biol. 9: 1436-1441. 
Llorente, B. and Symington, L.S. 2004. The Mre11 nuclease is not required for $5^{\prime}$ to $3^{\prime}$ resection at multiple HO-induced double-strand breaks. Mol. Cell. Biol. 24: 9682-9694.

Loayza, D. and de Lange, T. 2003. POT1 as a terminal transducer of TRF1 telomere length control. Nature 423: 10131018.

Longhese, M.P., Paciotti, V., Neecke, H., and Lucchini, G. 2000. Checkpoint proteins influence telomeric silencing and length maintenance in budding yeast. Genetics 155: 15771591.

Longhese, M.P., Mantiero, D., and Clerici, M. 2006. The cellular response to chromosome breakage. Mol. Microbiol. 60: 1099-1108.

Lundblad, V. 2002. Telomere maintenance without telomerase. Oncogene 21: 522-531.

Lundblad, V. and Blackburn, E.H. 1993. An alternative pathway for yeast telomere maintenance rescues est1- senescence. Cell 73: 347-360.

Lundblad, V. and Szostak, J.W. 1989. A mutant with a defect in telomere elongation leads to senescence in yeast. Cell 57: 633-643.

Lydall, D. and Weinert, T. 1995. Yeast checkpoint genes in DNA damage processing: Implications for repair and arrest. Science 270: 1488-1491.

Majka, J., Niedziela-Majka, A., and Burgers, P.M. 2006. The checkpoint clamp activates Mec1 kinase during initiation of the DNA damage checkpoint. Mol. Cell 24: 891-901.

Makarov, V.L., Hirose, Y., and Langmore, J.P. 1997. Long G tails at both ends of human chromosomes suggest a $\mathrm{C}$ strand degradation mechanism for telomere shortening. Cell 88: 657-666.

Makovets, S., Herskowitz, I., and Blackburn, E.H. 2004. Anatomy and dynamics of DNA replication fork movement in yeast telomeric regions. Mol. Cell. Biol. 24: 4019-4031.

Mantiero, D., Clerici, M., Lucchini, G., and Longhese, M.P. 2007. Dual role for Saccharomyces cerevisiae Tell in the checkpoint response to double-strand breaks. EMBO Rep. 8: 380-387.

Marcand, S., Gilson, E., and Shore, D. 1997. A protein-counting mechanism for telomere length regulation in yeast. Science 275: 986-990.

Marcand, S., Brevet, V., Mann, C., and Gilson, E. 2000. Cell cycle restriction of telomere elongation. Curr. Biol. 10: 487490.

Maringele, L. and Lydall, D. 2002. EXO1-dependent singlestranded DNA at telomeres activates subsets of DNA damage and spindle checkpoint pathways in budding yeast yku70s mutants. Genes \& Dev. 16: 1919-1933.

Maringele, L. and Lydall, D. 2004. EXO1 plays a role in generating type I and type II survivors in budding yeast. Genetics 166: 1641-1649.

Matsuura, A., Naito, T., and Ishikawa, F. 1999. Genetic control of telomere integrity in Schizosaccharomyces pombe: $\mathrm{rad}^{+}$ and tel1 $1^{+}$are parts of two regulatory networks independent of the downstream protein kinases $c h k 1^{+}$and $\mathrm{cds}^{+}$. Genetics 152: 1501-1512.

Metcalfe, J.A., Parkhill, J., Campbell, L., Stacey, M., Biggs, P., Byrd, P.J., and Taylor, A.M. 1996. Accelerated telomere shortening in ataxia telangiectasia. Nat. Genet. 13: 350-353.

Michelson, R.J., Rosenstein, S., and Weinert, T. 2005. A telomeric repeat sequence adjacent to a DNA double-stranded break produces an anticheckpoint. Genes \& Dev. 19: 25462559.

Mieczkowski, P.A., Mieczkowska, J.O., Dominska, M., and Petes, T.D. 2003. Genetic regulation of telomere-telomere fusions in the yeast Saccharomyces cerevisiae. Proc. Natl.
Acad. Sci. 100: 10854-10859.

Miller, K.M., Ferreira, M.G., and Cooper, J.P. 2005. Taz1, Rap1 and Rif1 act both interdependently and independently to maintain telomeres. EMBO J. 24: 3128-3135.

Morales, M., Theunissen, J.W., Kim, C.F., Kitagawa, R., Kastan, M.B., and Petrini, J.H. 2005. The Rad50S allele promotes ATM-dependent DNA damage responses and suppresses ATM deficiency: Implications for the Mre11 complex as a DNA damage sensor. Genes \& Dev. 19: 3043-3054.

Moreau, S., Ferguson, J.R., and Symington, L.S. 1999. The nuclease activity of Mrel1 is required for meiosis but not for mating type switching, end joining, or telomere maintenance. Mol. Cell. Biol. 19: 556-566.

Muñoz-Jordán, J.L., Cross, G.A., de Lange, T., and Griffith, J.D. 2001. t-loops at trypanosome telomeres. EMBO J. 20: 579588.

Muntoni, A. and Reddel, R.R. 2005. The first molecular details of ALT in human tumor cells. Hum. Mol. Genet. 14: R191R196. doi: 10.1093/hmg/ddi266.

Murti, K.G. and Prescott, D.M. 1999. Telomeres of polytene chromosomes in a ciliated protozoan terminate in duplex DNA loops. Proc. Natl. Acad. Sci. 96: 14436-14439.

Myers, J.S. and Cortez, D. 2006. Rapid activation of ATR by ionizing radiation requires ATM and Mre11. J. Biol. Chem. 281: 9346-9350.

Naito, T., Matsuura, A., and Ishikawa, F. 1998. Circular chromosome formation in a fission yeast mutant defective in two ATM homologues. Nat. Genet. 20: 203-206.

Nakada, D., Matsumoto, K., and Sugimoto, K. 2003. ATM-related Tell associates with double-strand breaks through an Xrs2-dependent mechanism. Genes \& Dev. 17: 1957-1962.

Nakamura, T.M., Moser, B.A., and Russell, P. 2002. Telomere binding of checkpoint sensor and DNA repair proteins contributes to maintenance of functional fission yeast telomeres. Genetics 161: 1437-1452.

Negrini, S., Ribaud, V., Bianchi, A., and Shore, D. 2007. DNA breaks are masked by multiple Rapl binding in yeast: Implications for telomere capping and telomerase regulation. Genes \& Dev. 21: 292-302.

Nugent, C.I., Hughes, T.R., Lue, N.F., and Lundblad, V. 1996. Cdc13p: A single-strand telomeric DNA-binding protein with a dual role in yeast telomere maintenance. Science $\mathbf{2 7 4}$ : 249-252.

O'Connor, M.S., Safari, A., Liu, D., Qin, J., and Songyang, Z. 2004. The human Rap1 protein complex and modulation of telomere length. J. Biol. Chem. 279: 28585-28591.

Paciotti, V., Clerici, M., Lucchini, G., and Longhese, M.P. 2000. The checkpoint protein Ddc2, functionally related to $S$. pombe Rad26, interacts with Mec1 and is regulated by Mec1-dependent phosphorylation in budding yeast. Genes \& Dev. 14: 2046-2059.

Pardo, B. and Marcand, S. 2005. Rap1 prevents telomere fusions by nonhomologous end joining. EMBO J. 24: 3117-3127.

Parkinson, G.N., Lee, M.P., and Neidle, S. 2002. Crystal structure of parallel quadruplexes from human telomeric DNA. Nature 417: 876-880.

Pennaneach, V. and Kolodner, R.D. 2004. Recombination and the Tell and Mec1 checkpoints differentially effect genome rearrangements driven by telomere dysfunction in yeast. Nat. Genet. 36: 612-617.

Pennock, E., Buckley, K., and Lundblad, V. 2001. Cdc13 delivers separate complexes to the telomere for end protection and replication. Cell 104: 387-396.

Peterson, S.E., Stellwagen, A.E., Diede, S.J., Singer, M.S., Haimberger, Z.W., Johnson, C.O., Tzoneva, M., and Gottschling, D.E. 2001. The function of a stem-loop in telomerase RNA 
is linked to the DNA repair protein Ku. Nat. Genet. 27: 64-67.

Pitt, C.W., Valente, L.P., Rhodes, D., and Simonsson, T. 2007. Identification and characterization of an essential telomeric repeat binding factor in Schizosaccharomyces pombe. I. Biol. Chem. doi: 10.1074/jbc.M708784200.

Polotnianka, R.M., Li, J., and Lustig, A.J. 1998. The yeast Ku heterodimer is essential for protection of the telomere against nucleolytic and recombinational activities. Curr. Biol. 8: 831-834.

Ritchie, K.B. and Petes, T.D. 2000. The Mre11/Rad50/Xrs2 complex and the Tell function in a single pathway for telomere maintenance in yeast. Genetics 155: 475-479.

Ritchie, K.B., Mallory, J.C., and Petes, T.D. 1999. Interactions of TLC1 (which encodes the RNA subunit of telomerase), TEL1, and MEC1 in regulating telomere length in the yeast Saccharomyces cerevisiae. Mol. Cell. Biol. 19: 6065-6075.

Sabourin, M., Tuzon, C.T., and Zakian, V.A. 2007. Telomerase and Tellp preferentially associate with short telomeres in $S$. cerevisiae. Mol. Cell 27: 550-561.

Schramke, V., Luciano, P., Brevet, V., Guillot, S., Corda, Y., Longhese, M.P., Gilson, E., and Geli, V. 2004. RPA regulates telomerase action by providing Est $1 \mathrm{p}$ access to chromosome ends. Nat. Genet. 36: 46-54.

Shiloh, Y. 2006. The ATM-mediated DNA-damage response: Taking shape. Trends Biochem. Sci. 31: 402-410.

Smogorzewska, A., van Steensel, B., Bianchi, A., Oelmann, S., Schaefer, M.R., Schnapp, G., and de Lange, T. 2000. Control of human telomere length by TRF1 and TRF2. Mol. Cell. Biol. 20: 1659-1668.

Smogorzewska, A., Karlseder, J., Holtgreve-Grez, H., Jauch, A., and de Lange, T. 2002. DNA ligase IV-dependent NHEJ of deprotected mammalian telomeres in G1 and G2. Curr. Biol. 12: $1635-1644$.

Song, K., Jung, D., Jung, Y., Lee, S.G., and Lee, I. 2000. Interaction of human Ku70 with TRF2. FEBS Lett. 481: 81-85.

Stansel, R.M., de Lange, T., and Griffith, J.D. 2001. T-loop assembly in vitro involves binding of TRF2 near the $3^{\prime}$ telomeric overhang. EMBO J. 20: 5532-5540.

Stellwagen, A.E., Haimberger, Z.W., Veatch, J.R., and Gottschling, D.E. 2003. Ku interacts with telomerase RNA to promote telomere addition at native and broken chromosome ends. Genes \& Dev. 17: 2384-2395.

Sweeney, F.D., Yang, F., Chi, A., Shabanowitz, J., Hunt, D.F., and Durocher, D. 2005. Saccharomyces cerevisiae Rad9 acts as a Mec1 adaptor to allow Rad53 activation. Curr. Biol. 15: $1364-1375$.

Taggart, A.K., Teng, S.C., and Zakian, V.A. 2002. Est1p as a cell cycle-regulated activator of telomere-bound telomerase. Science 297: 1023-1026.

Takai, H., Smogorzewska, A., and de Lange, T. 2003. DNA damage foci at dysfunctional telomeres. Curr. Biol. 13: 15491556.

Takata, H., Tanaka, Y., and Matsuura, A. 2005. Late S phasespecific recruitment of Mrel1 complex triggers hierarchical assembly of telomere replication proteins in Saccharomyces cerevisiae. Mol. Cell 17: 573-583.

Tanaka, H., Mendonca, M.S., Bradshaw, P.S., Hoelz, D.J., Malkas, L.H., Meyn, M.S., and Gilley, D. 2005. DNA damage-induced phosphorylation of the human telomere-associated protein TRF2. Proc. Nat1. Acad. Sci. 102: 15539-15544.

Teixeira, M.T., Arneric, M., Sperisen, P., and Lingner, J. 2004. Telomere length homeostasis is achieved via a switch between telomerase-extendible and -nonextendible states. Cell 117: 323-335.

Tseng, S.F., Lin, J.J., and Teng, S.C. 2006. The telomerase-re- cruitment domain of the telomere binding protein $\mathrm{Cdc} 13$ is regulated by Meclp/Tellp-dependent phosphorylation. Nucleic Acids Res. 34: 6327-6336.

Tsolou, A. and Lydall, D. 2007. Mrc1 protects uncapped budding yeast telomeres from exonuclease EXO1. DNA Repair (Amst.) 6: 1607-1617.

Usui, T., Ogawa, H., and Petrini, J.H. 2001. A DNA damage response pathway controlled by Tell and the Mre11 complex. Mol. Cell 7: 1255-1266.

van Overbeek, M. and de Lange, T. 2006. Apollo, an Artemisrelated nuclease, interacts with TRF2 and protects human telomeres in S phase. Curr. Biol. 16: 1295-1302.

van Steensel, B. and de Lange, T. 1997. Control of telomere length by the human telomeric protein TRF1. Nature 385: 740-743.

van Steensel, B., Smogorzewska, A., and de Lange, T. 1998. TRF2 protects human telomeres from end-to-end fusions. Cell 92: 401-413.

Veldman, T., Etheridge, K.T., and Counter, C.M. 2004. Loss of hPot 1 function leads to telomere instability and a cut-like phenotype. Curr. Biol. 14: 2264-2270.

Verdun, R.E. and Karlseder, J. 2006. The DNA damage machinery and homologous recombination pathway act consecutively to protect human telomeres. Cell 127: 709-720.

Verdun, R.E., Crabbe, L., Haggblom, C., and Karlseder, J. 2005. Functional human telomeres are recognized as DNA damage in G2 of the cell cycle. Mol. Cell 20: 551-561.

Viscardi, V., Baroni, E., Romano, M., Lucchini, G., and Longhese, M.P. 2003. Sudden telomere lengthening triggers a Rad53-dependent checkpoint in Saccharomyces cerevisiae. Mol. Biol. Cell 14: 3126-3143.

Viscardi, V., Clerici, M., Cartagena-Lirola, H., and Longhese, M.P. 2005. Telomeres and DNA damage checkpoints. Biochimie 87: 613-624.

Viscardi, V., Bonetti, D., Cartagena-Lirola, H., Lucchini, G., and Longhese, M.P. 2007. MRX-dependent DNA damage response to short telomeres. Mol. Biol. Cell 18: 3047-3058.

Vodenicharov, M.D. and Wellinger, R.J. 2006. DNA degradation at unprotected telomeres in yeast is regulated by the CDK1 (Cdc28/Clb) cell-cycle kinase. Mol. Cell 24: 127-137.

Wang, R.C., Smogorzewska, A., and de Lange, T. 2004. Homologous recombination generates T-loop-sized deletions at human telomeres. Cell 119: 355-368.

Wellinger, R.J., Wolf, A.J., and Zakian, V.A. 1993. Saccharomyces telomeres acquire single-strand TG1-3 tails late in S phase. Cell 72: 51-60.

Wellinger, R.J., Ethier, K., Labrecque, P., and Zakian, V.A. 1996. Evidence for a new step in telomere maintenance. Cell 85: 423-433.

Williams, R.S., Williams, J.S., and Tainer, J.A. 2007. Mre11Rad50-Nbs1 is a keystone complex connecting DNA repair machinery, double-strand break signaling, and the chromatin template. Biochem. Cell Biol. 85: 509-520.

Wright, W.E., Tesmer, V.M., Huffman, K.E., Levene, S.D., and Shay, J.W. 1997. Normal human chromosomes have long G-rich telomeric overhangs at one end. Genes \& Dev. 11: 2801-2809.

Wu, L., Multani, A.S., He, H., Cosme-Blanco, W., Deng, Y., Deng, J.M., Bachilo, O., Pathak, S., Tahara, H., Bailey, S.M., et al. 2006. Pot1 deficiency initiates DNA damage checkpoint activation and aberrant homologous recombination at telomeres. Cell 126: 49-62.

Wu, Y., Xiao, S., and Zhu, X.D. 2007. MRE11-RAD50-NBS1 and ATM function as co-mediators of TRF1 in telomere length control. Nat. Struct. Mol. Biol. 14: 832-840.

Yang, Q., Zheng, Y.L., and Harris, C.C. 2005. POT1 and TRF2 
Longhese

cooperate to maintain telomeric integrity. Mol. Cell. Biol. 25: $1070-1080$.

Ye, J.Z., Donigian, J.R., Van Overbeek, M., Loayza, D., Luo, Y., Krutchinsky, A.N., Chait, B.T., and de Lange, T. 2004a. TIN2 binds TRF1 and TRF2 simultaneously and stabilizes the TRF2 complex on telomeres. J. Biol. Chem. 279: 47264 47271.

Ye, J.Z., Hockemeyer, D., Krutchinsky, A.N., Loayza, D., Hooper, S.M., Chait, B.T., and de Lange, T. 2004b. POT1interacting protein PIP1: A telomere length regulator that recruits POT1 to the TIN2/TRF1 complex. Genes \& Dev. 18: 1649-1654.

You, Z., Chahwan, C., Bailis, J., Hunter, T., and Russell, P. 2005. ATM activation and its recruitment to damaged DNA require binding to the $\mathrm{C}$ terminus of Nbs1. Mol. Cell. Biol. 25: 5363-5379.

Zhu, X.D., Kuster, B., Mann, M., Petrini, J.H., and de Lange, T. 2000. Cell-cycle-regulated association of RAD50/MRE11/ NBS1 with TRF2 and human telomeres. Nat. Genet. 25: 347-352.

Zhu, X.D., Niedernhofer, L., Kuster, B., Mann, M., Hoeijmakers, J.H., and de Lange, T. 2003. ERCC1/XPF removes the 3 ' overhang from uncapped telomeres and represses formation of telomeric DNA-containing double minute chromosomes. Mol. Cell 12: 1489-1498.

Zou, L. and Elledge, S.J. 2003. Sensing DNA damage through ATRIP recognition of RPA-ssDNA complexes. Science 300: 1542-1548.

Zubko, M.K., Guillard, S., and Lydall, D. 2004. Exo1 and Rad24 differentially regulate generation of ssDNA at telomeres of Saccharomyces cerevisiae cdc13-1 mutants. Genetics 168: 103-115. 


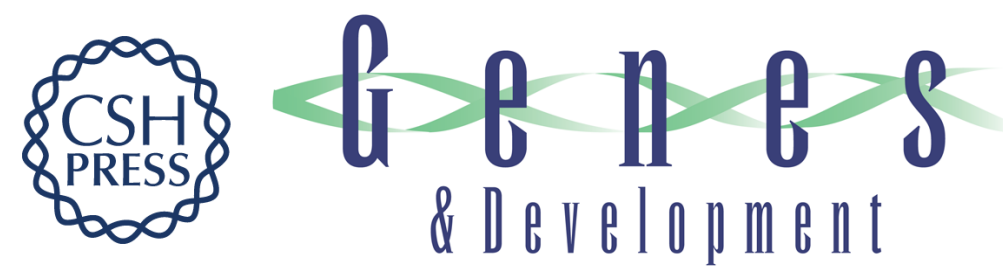

\section{DNA damage response at functional and dysfunctional telomeres}

Maria Pia Longhese

Genes Dev. 2008, 22:

Access the most recent version at doi:10.1101/gad.1626908

References This article cites 179 articles, 75 of which can be accessed free at: http://genesdev.cshlp.org/content/22/2/125.full.html\#ref-list-1

License

Email Alerting Receive free email alerts when new articles cite this article - sign up in the box at the top Service right corner of the article or click here.

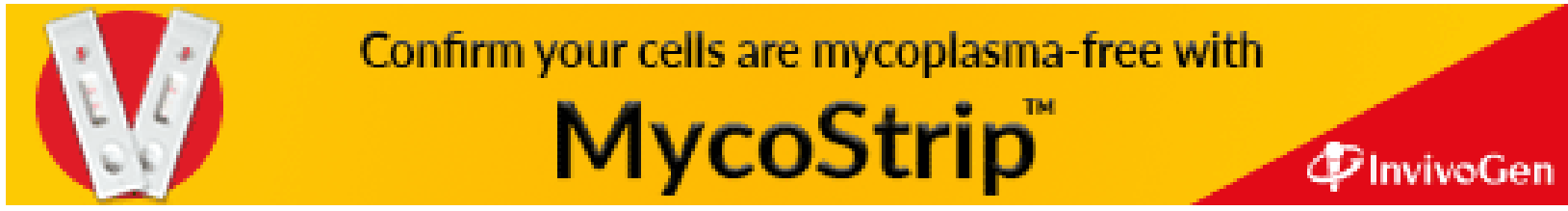

